\title{
Effects of High-Octane Ethanol Blends on Four Legacy Flex-Fuel Vehicles, and a Turbocharged GDI Vehicle
}
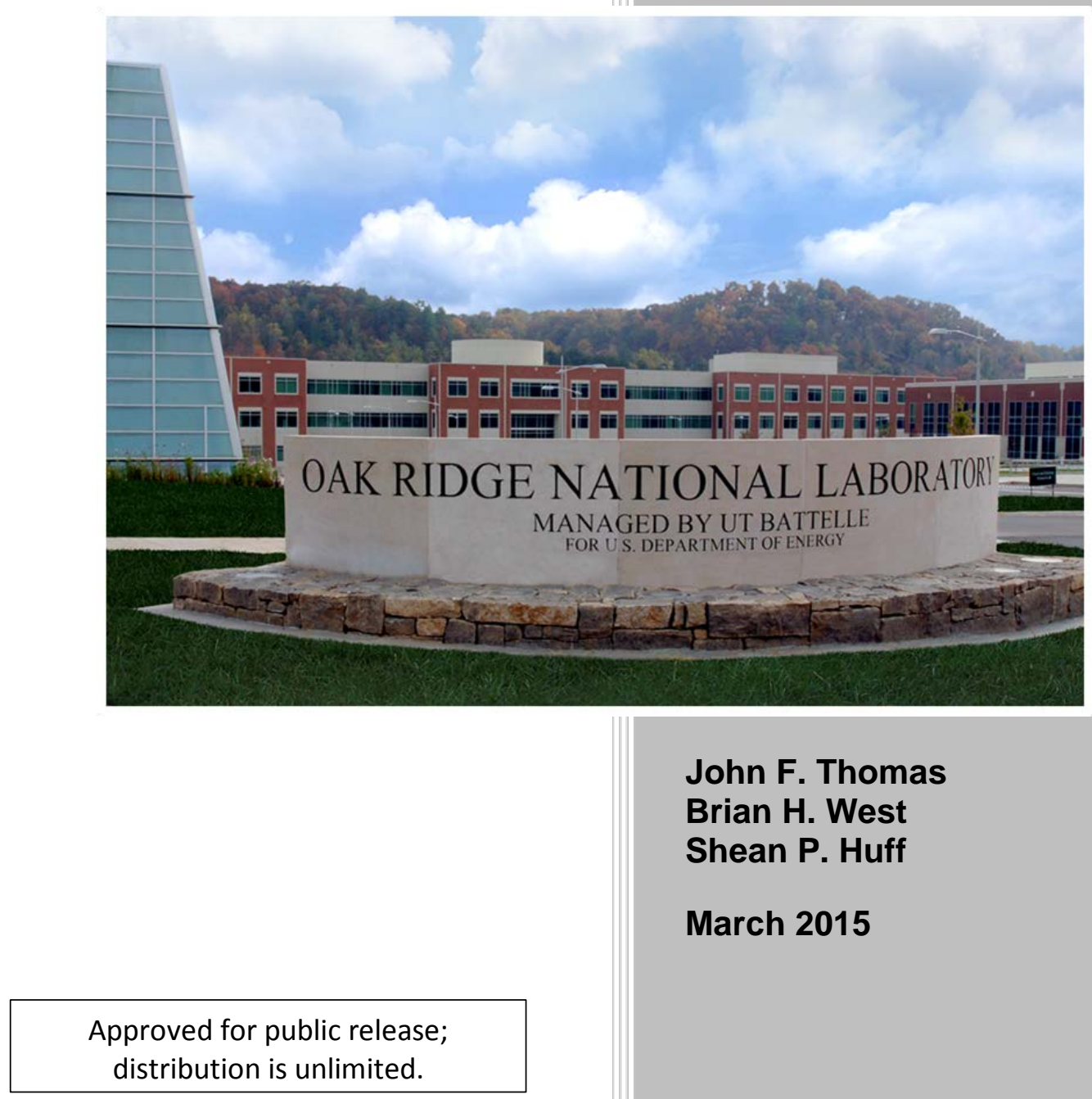

John F. Thomas

Brian H. West

Shean P. Huff

March 2015 


\title{
DOCUMENT AVAILABILITY
}

Reports produced after January 1, 1996, are generally available free via US Department of Energy (DOE) SciTech Connect.

\section{Website http://www.osti.gov/scitech/}

Reports produced before January 1, 1996, may be purchased by members of the public from the following source:

\author{
National Technical Information Service \\ 5285 Port Royal Road \\ Springfield, VA 22161 \\ Telephone 703-605-6000 (1-800-553-6847) \\ TDD 703-487-4639 \\ Fax 703-605-6900 \\ E-mail info@ntis.gov \\ Website http://www.ntis.gov/help/ordermethods.aspx
}

Reports are available to DOE employees, DOE contractors, Energy Technology Data Exchange representatives, and International Nuclear Information System representatives from the following source:

Office of Scientific and Technical Information

PO Box 62

Oak Ridge, TN 37831

Telephone 865-576-8401

Fax 865-576-5728

E-mail reports@osti.gov

Website http://www.osti.gov/contact.html

This report was prepared as an account of work sponsored by an agency of the United States Government. Neither the United States Government nor any agency thereof, nor any of their employees, makes any warranty, express or implied, or assumes any legal liability or responsibility for the accuracy, completeness, or usefulness of any information, apparatus, product, or process disclosed, or represents that its use would not infringe privately owned rights. Reference herein to any specific commercial product, process, or service by trade name, trademark, manufacturer, or otherwise, does not necessarily constitute or imply its endorsement, recommendation, or favoring by the United States Government or any agency thereof. The views and opinions of authors expressed herein do not necessarily state or reflect those of the United States Government or any agency thereof. 


\title{
EFFECTS OF HIGH OCTANE ETHANOL BLENDS ON FOUR LEGACY FLEX-FUEL VEHICLES, AND A TURBOCHARGED GDI VEHICLE
}

\author{
John Thomas \\ Brian West \\ Shean Huff \\ Oak Ridge National Laboratory
}

Date Published: March 2015

Prepared by

OAK RIDGE NATIONAL LABORATORY

Oak Ridge, Tennessee 37831-6283

managed by

UT-BATTELLE, LLC

for the

U.S. DEPARTMENT OF ENERGY

under contract DE-AC05-00OR22725 



\section{CONTENTS}

Page

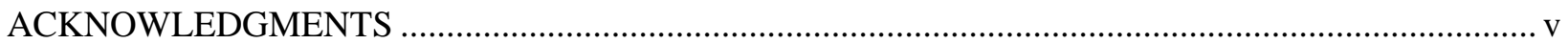

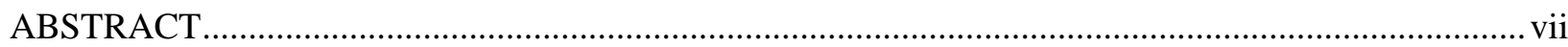

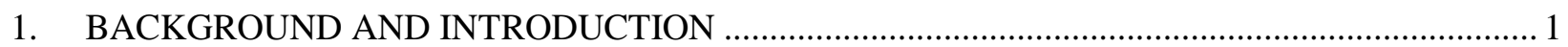

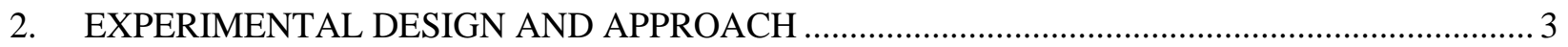

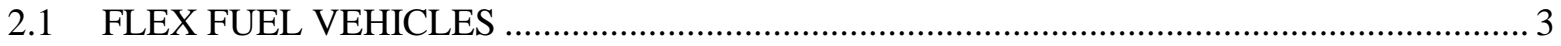

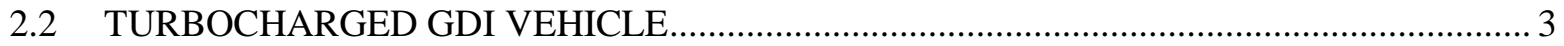

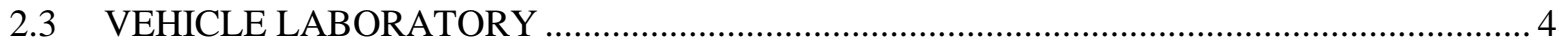

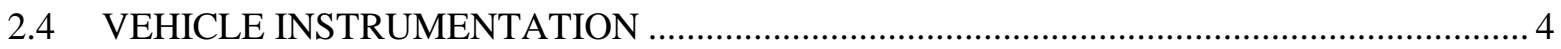

2.5 FLEX-FUEL VEHICLE TEST SEQUENCE AND FUELS ......................................... 4

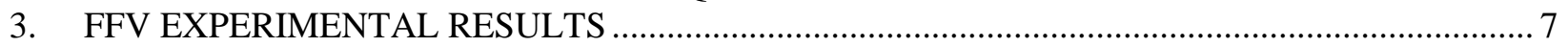

3.1 EFFECT OF AIR DENSITY AND OXYGEN CONTENT ON MAXIMUM POWER............ 7

3.2 WOT PERFORMANCE RESULTS FOR FLEX FUEL VEHICLES.................................. 8

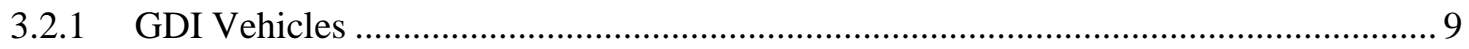

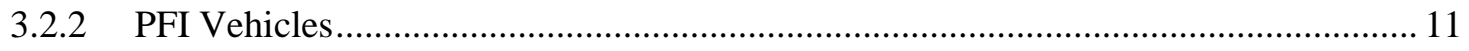

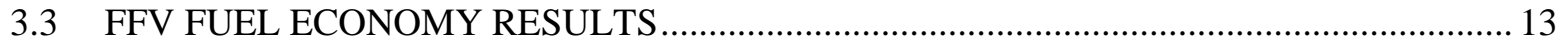

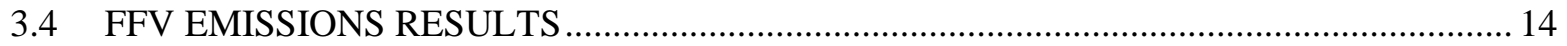

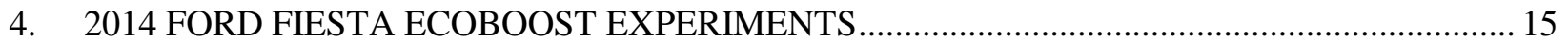

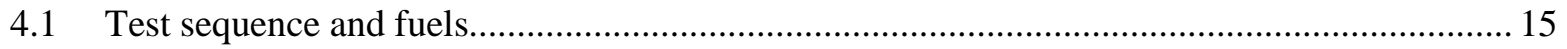

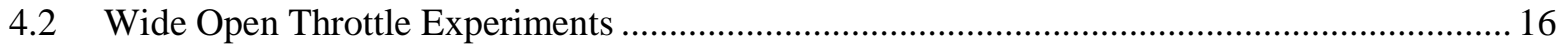

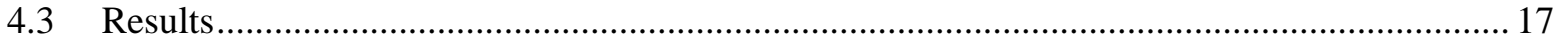

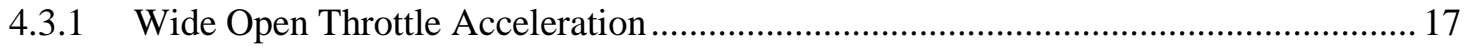

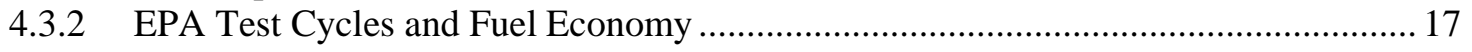

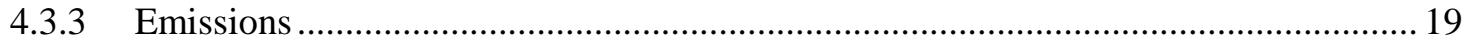

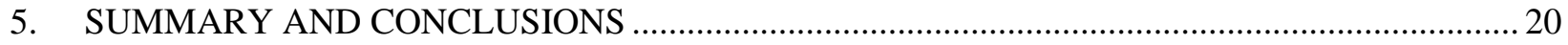

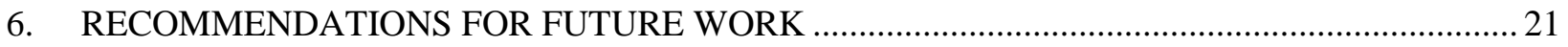

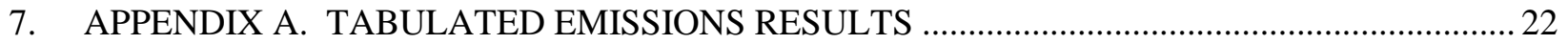





\section{ACKNOWLEDGMENTS}

This report and the work described were sponsored by the U.S. Department of Energy (DOE) Bioenergy Technologies Office (BETO) and Vehicle Technologies Office (VTO). The authors gratefully acknowledge the support and direction of Alicia Lindauer and Jim Spaeth at BETO, and Dennis Smith and Kevin Stork at VTO. The assistance with the flex-fuel vehicle registrations in the Polk database provided by Caley Johnson and George Mitchell at the National Renewable Energy Laboratory is greatly appreciated. The authors are indebted to Larry Moore for his expert assistance in the vehicle laboratory, and to Ron Graves, Tim Theiss, and Robert Wagner at ORNL for their programmatic vision. The acquisition of test vehicles by Tom Vicary at Sexton Automotive Group is also greatly appreciated. The authors also thank Jim Szybist for his thorough review of the manuscript.

The authors are indebted to several colleagues in industry and government. While these colleagues provided valuable guidance and information, this consultation does not constitute endorsement by their organizations of either the study or the results. 


\begin{abstract}
The U.S. Department of Energy (DOE) is supporting engine and vehicle research to investigate the potential of high-octane fuels to improve fuel economy. Ethanol has very high research octane number (RON) and heat of vaporization (HoV), properties that make it an excellent spark ignition engine fuel. The prospects of increasing both the ethanol content and the octane number of the gasoline pool has the potential to enable improved fuel economy in future vehicles with downsized, downsped engines. This report describes a small study to explore the potential performance benefits of high octane ethanol blends in the legacy fleet. There are over 17 million flex-fuel vehicles (FFVs) on the road today in the United States, vehicles capable of using any fuel from E0 to E85. If a future high-octane blend for dedicated vehicles is on the horizon, the nation is faced with the classic chicken-and-egg dilemma. If today's FFVs can see a performance advantage with a high octane ethanol blend such as E25 or E30, then perhaps consumer demand for this fuel can serve as a bridge to future dedicated vehicles.

Experiments were performed with four FFVs using a 10\% ethanol fuel (E10) with 88 pump octane, and a market gasoline blended with ethanol to make a $30 \%$ by volume ethanol fuel (E30) with 94 pump octane. The research octane numbers were 92.4 for the E10 fuel and 100.7 for the E30 fuel. Two vehicles had gasoline direct injected (GDI) engines, and two featured port fuel injection (PFI). Significant wide open throttle (WOT) performance improvements were measured for three of the four FFVs, with one vehicle showing no change. Additionally, a conventional (non-FFV) vehicle with a small turbocharged directinjected engine was tested with a regular grade of gasoline with no ethanol (E0) and a splash blend of this same fuel with 15\% ethanol by volume (E15). RON was increased from 90.7 for the E0 to 97.8 for the E15 blend. Significant wide open throttle and thermal efficiency performance improvement was measured for this vehicle, which achieved near volumetric fuel economy parity on the aggressive US06 drive cycle, demonstrating the potential for improved fuel economy in forthcoming downsized, downsped engines with high-octane fuels.
\end{abstract}




\section{BACKGROUND AND INTRODUCTION}

The Energy Independence and Security Act of 2007* requires significant increases in the nation's use of renewable fuels to meet its transportation energy needs. The law established a renewable fuel standard (RFS) that requires the nation to use 36 billion gallons of renewable fuel per year in its vehicles by 2022. Ethanol is the most widely used renewable fuel in the United States, and most of it is blended with gasoline to create E10 - gasoline with up to 10\% ethanol. In 2010 and 2011 the EPA approved the use of E15 in 2001 and newer light-duty vehicles ${ }^{\dagger, \ddagger}$ however as of May 2014 less than 100 fuel stations were selling E15. ${ }^{\S}$ Although ethanol consumption has exceed 13 billion gallons per year (Bgpy) for the past several years, the path toward RFS compliance is not clear because a "blend wall" is encountered with E10 and E15, and "E85" consumption remains limited ( $<1 \%$ of ethanol consumption).

Concurrent with RFS requirements for renewable fuel consumption, $\mathrm{CO}_{2}$ emissions from vehicles are required to decrease with dramatic increases in fuel economy. Vehicle manufacturers are pursuing a wide range of technologies to reduce $\mathrm{CO}_{2}$ emissions, including engine technologies such as downsized and downsped turbocharged engines which could benefit from improved anti-knock properties of fuel.

Recently published data ${ }^{* *,+\dagger, \ddagger \ddagger £ \S}$ highlight the potential fuel economy benefits of high-octane fuels that take advantage of ethanol's properties in a mid-level blend. A "Renewable Super Premium" (RSP) study has been underway since 2014 under the auspices of the Bioenergy Technologies Office at DOE. A team of national laboratories (ORNL, NREL, and ANL) are investigating the potential benefits of a fuel with 25-40 vol\% ethanol to raise octane and enable improved fuel economy and decreased GHG emissions. With $5 \%$ to $10 \%$ thermal efficiency improvement feasible, volumetric fuel economy parity can be realized with these blends. This parity is defined as the future vehicle with a downsized, turbocharged direct-injection engine fueled with a high-octane mid-level ethanol blend achieving the same "tank mileage” as a conventional vehicle with today’s E10, despite the high-octane blend having 5 to $10 \%$ lower energy density.

One attractive prospect of such a fuel is that it could be used legally in more than 17 million FFVs on the road today. Thus, the current FFV fleet might serve as a bridge by providing a near-term market for the fuel, making it widely available such that future vehicles optimized for the new high-octane fuel can realize improved efficiency.

Limited ethanol use in FFVs is often attributed to limited E85 infrastructure. Unfavorable pricing (on a \$/BTU or \$/mile basis) and reduced mpg cannot be overlooked as additional important contributors to the limited use of E85 or Flex Fuel. ${ }^{* * *}$ If a new high-octane mid-level ethanol blend for future vehicles is on the horizon, it could be beneficial to begin building out this fueling infrastructure now. Many Flex Fuel

\footnotetext{
${ }^{*}$ H.R. $6\left(110^{\text {th }}\right)$ : Energy Independece and Security Act of 2007, 12/19/2007, available at: http://www.govtrack.us/congress/bills/110/hr6/text

${ }^{\dagger}$ Federal Register, Vol. 75(213), Thursday, November 4, 2010, Notices.

${ }^{\ddagger}$ Federal Register, Vol. 76(17), Wednesday, January 26, 2011, Notices.

${ }^{\S}$ Renewable Fuels Association, available at: http://ethanolrfa.3cdn.net/5e33853b732498fff8_nwm6b5j56.pdf

${ }^{* *}$ Leone, T., Olin, E., Anderson, J., Jung, H. et al., "Effects of Fuel Octane Rating and Ethanol Content on Knock, Fuel Economy, and CO2 for a Turbocharged DI Engine," SAE Int. J. Fuels Lubr. 7(1):9-28, 2014, doi:10.4271/2014-01-1228

${ }^{+}$Splitter, D.A., and Szybist, J.P., "Experimental Investigation of Spark-Ignited Combustion with High-Octane Biofuels and EGR. 2. Fuel and EGR Effects on Knock-Limited Load and Speed,” Energy \& Fuels, 28(2): 1432-1445, 2014, doi:10.1021/ef401575e

执Jung, H., Leone, T., Shelby, M., Anderson, J. et al., "Fuel Economy and CO2 Emissions of Ethanol-Gasoline Blends in a Turbocharged DI Engine," SAE Int. J. Engines 6(1):422-434, 2013, doi:10.4271/2013-01-1321.

$\S \S$ Splitter, D. and Szybist, J., "Intermediate Alcohol-Gasoline Blends, Fuels for Enabling Increased Engine Efficiency and Powertrain Possibilities," SAE Int. J. Fuels Lubr. 7(1):2014, doi:10.4271/2014-01-1231.

*** Thomas, J. F., S. P. Huff, and B. H. West, "Fuel Economy and Emissions of a Vehicle Equipped with an Aftermarket Flexible-Fuel Conversion Kit,” ORNL/TM-2011/483, April 2012.
} 
blender pumps offer a range of fuels today, often including E30. Marketing a fuel such as high-octane E30 as "Renewable Super Premium for your FFV" could help grow the infrastructure, provided the fuel is priced and marketed effectively. EPA's Tier 3 rule $^{*}$ contains language that allows manufacturers to request approval for an alternative certification fuel such as a high-octane E30. Before vehicles requiring this fuel can be offered for sale, the fuel needs to be widely available (much like unleaded gasoline was available in 1975 before vehicles requiring it were sold, or similarly the way that ultra-low sulfur diesel fuel was available in 2006 prior to the sale of 2007 diesel engines that required it). Over 17 million FFVs on the road today can legally use such a fuel, but consumers need some incentive to purchase the fuel.

This report describes experiments on five vehicles. The experiments and results showing the effects and performance benefits of high-octane E30 fuel on four FFVs are described in Sections 2 and 3. Section 4 covers analogous experiments, but using different fuels, with a non-flex fuel vehicle powered by a small turbocharged DI engine. For this latter vehicle the allowable ethanol fuel content is limited to $15 \%$. A brief summary with conclusions is given in Section 5, and future work is discussed briefly in Section 6.

*Federal Register, Vol. 79(81), Monday, April 28,2014, Rules and Regulations (Tier 3 Emissions and Fuel Standards). 


\section{EXPERIMENTAL DESIGN AND APPROACH}

\subsection{FLEX FUEL VEHICLES}

Four flex-fuel vehicles (FFVs) were selected based on a review of the legacy FFV fleet for model years 2006 through 2012. General Motors, Ford, and Chrysler have produced significantly more FFVs than other manufacturers. As of January 2013, over half the registered 2006 through 2012 model year FFVs were manufactured by General Motors. To capture a reasonable variety in engine and vehicle type, the vehicles shown in Table 2.1 were selected. All of the selected FFV engines were normally-aspirated. While turbocharged engines would no doubt take greater advantage of the increased ethanol and octane, the sales numbers of this engine technology in flex-fuel vehicles are still quite small compared to the legacy fleet. Two FFVs feature engines with GDI, and two feature PFI. Even without turbocharging, there is an expectation that GDI engines can take more advantage from ethanol compared to PFI, particularly due to increased charge cooling effect from ethanol's higher $\mathrm{HoV}$.

Table 2.1. Flex-Fuel vehicles used in study

\begin{tabular}{|c|c|c|c|c|c|c|}
\hline $\begin{array}{l}\text { Model } \\
\text { year }\end{array}$ & $\begin{array}{l}\text { Vehicle } \\
\text { model }\end{array}$ & $\begin{array}{l}\text { Engine family } \\
\text { number }\end{array}$ & $\begin{array}{c}\text { Engine } \\
\text { displacement } \\
\text { (liters) }\end{array}$ & $\begin{array}{c}\text { Engine } \\
\text { configuration }\end{array}$ & $\begin{array}{l}\text { Transmission, } \\
\text { drive axle }\end{array}$ & $\begin{array}{c}\text { Odometer } \\
\text { (miles) }\end{array}$ \\
\hline 2014 & GMC Sierra & EGMXT04.3187 & 4.3 & V6, GDI ${ }^{\mathrm{a}}$ & $\mathrm{A}^{\mathrm{b}}, \mathrm{RWD}^{\mathrm{c}}$ & 6,800 \\
\hline 2014 & $\begin{array}{l}\text { Chevrolet } \\
\text { Impala }\end{array}$ & EGMXJ03.6166 & 3.6 & V6, GDI & A6, FWD ${ }^{d}$ & 23,300 \\
\hline 2013 & Dodge & DCRXJ03.6VPA & 3.6 & V6, $\mathrm{PFI}^{\mathrm{e}}$ & A6, FWD & 53,800 \\
\hline 2013 & Ford F150 & DFMXT05.03D7 & 5.0 & V8, PFI & A6, RWD & 7,700 \\
\hline $\begin{array}{l}{ }^{\mathrm{a}} \text { Gasolin } \\
\text { b Automa } \\
{ }^{\mathrm{c}} \text { Rear-W } \\
{ }^{\mathrm{d}} \text { Front-V } \\
{ }^{\mathrm{e}} \text { Port Fu }\end{array}$ & $\begin{array}{l}\text { Direct Injection } \\
6 \text {-speed trans } \\
\text { el Drive } \\
\text { eel Drive } \\
\text { Injection }\end{array}$ & ion & & & & \\
\hline
\end{tabular}

\subsection{TURBOCHARGED GDI VEHICLE}

A 2014 Ford Fiesta with a turbocharged 1.0L 3-cylinder GDI engine and 5-speed manual transmission was also tested, but with a different pair of fuels and a somewhat different test sequence. The Fiesta is not an FFV, and the use of regular 87 AKI gasoline is recommended - but Ford claims improved performance if premium grade fuel is used, and also permits the use of E15, ${ }^{*}$ thus a highoctane E15 blend was evaluated in this vehicle. The efforts and results with the Fiesta are described in Section 4.

\footnotetext{
* Ford Motor Company, 2014 Ford Fiesta Owner's Manual, available at http://www.fordservicecontent.com/Ford_Content/catalog/owner_guides/14fstom1e.pdf
} 


\subsection{VEHICLE LABORATORY}

Vehicle testing was performed at ORNL's Fuels, Engines, and Emission Research Center (FEERC). The vehicle research laboratory features a Burke E. Porter $300 \mathrm{hp}$ motor-in-the-middle, two-wheel drive, 48 inch, single roll AC motoring chassis dynamometer. Gaseous vehicle emissions are measured with conventional gas analyzers from California Analytical Instruments. The tunnel bench samples dilute exhaust from a constant volume sampling system (CVS, or dilution tunnel) and the CVS bag sampler is equipped with conventional non-dispersive infrared gas analyzers for $\mathrm{CO}$ and $\mathrm{CO}_{2}$; chemilumenescence analyzer for NOx; and a flame ionization detector (FID) with a methane cutter measures total hydrocarbons and $\mathrm{CH}_{4}$. Fuel economy and emission levels are calculated from the integrated emissions sampled from the CVS dilution tunnel, using the carbon mass balance method specified by EPA and Code of Federal Regulations guidelines. In addition, an Emerson Micro Motion CMF010M, Coriolis-effect type flow and density meter measures instantaneous and cumulative fuel consumption.

\subsection{VEHICLE INSTRUMENTATION}

All test vehicles were pre-owned and rented from a local dealer. No significant modifications were made to the vehicles for instrumentation. The important vehicle instrumentation included:

1. Thermocouple placed in the oil sump via the oil dipstick tube. Vehicle oil temperature was used as an indicator that the vehicle was in virtually the same thermal state at the beginning of each repeat test.

2. Controller-Area Network (CAN) tool connected to the OBD port for recording relevant engine data such as spark timing, rpm, and coolant temperature

3. Ambient test cell temperature measured between the vehicle cooling fan and the vehicle front grille, and

4. Coriolis mass flow meter installed for direct fuel consumption measurement

5. Vehicle exhaust connected to a full-flow, constant volume dilution tunnel with critical flow venturis for emissions measurement.

\subsection{FLEX-FUEL VEHICLE TEST SEQUENCE AND FUELS}

A consistent and repeatable test sequence was chosen to minimize variation in the vehicle state (thermal state of the test cell, powertrain, and tires), and to be sure all vehicles were evaluated with the same methodology. The protocol for a test day was as follows:

1. Cold city test also known as the (cold) FTP (nominally $25 \mathrm{C} / 77^{\circ} \mathrm{F}$ )

2. 20 minute soak,

3. Vehicle warmup (50 mph cruise, bring engine oil to $93 \mathrm{C} / 200^{\circ} \mathrm{F}$ )

4. Custom WOT test cycle (3 back-to-back WOTs)

5. 90 minute soak,

6. Vehicle warmup (step 3),

7. Highway fuel economy test (HFET),

8. 20 minute soak,

9. Vehicle warmup (step 3)

10. Custom WOT test (step 4) 
A Minimum of 2 days of test cycles was performed for each fuel (2 FTP and 2 HFET cycles and 4 WOT tests for each fuel). In some cases, some additional tests or a full additional day of testing was performed.

The FTP is performed after a "cold-soak" of 12 to 36 hours; a cold soak simply meaning the car sits at test cell temperature ( 68 to $86^{\circ} \mathrm{F}$, nominally $\left.77^{\circ} \mathrm{F}\right)$ to be in the "cold" state. Note that the HFET is run twice in succession (with 15 seconds of idle in between which is not part of the reduced data); the first test is a preparatory cycle and only the second cycle data is used for calculating emissions and fuel economy.

A rigorous fuel learning test sequence was used for each change of fuel to enable adequate adaption. The adaptation protocol included 5 minutes at $50 \mathrm{mph}$, an LA4 ${ }^{*}$ cycle, an LA92 ${ }^{\dagger}$ cycle, and two US06 $^{\ddagger}$ cycles. This fuel learning procedure was usually performed the afternoon before the first FTP (leaving 16 hours cold-soak until the FTP).

Properties of the two fuels used for the FFV experiments are shown in Table 2.2. The E10 was a CARB LEV III certification gasoline provided by Haltermann. Corrigan Oil provided the E30 fuel by splash blending ethanol with a market gasoline. Fuel analyses were provided by Johann Haltermann Ltd. and Southwest Research Institute. Note that the Haltermann CARB fuel has a higher energy density than a typical E10 fuel; had these two ethanol blends been produced from the same blendstock, the energy density ratio would be closer to $93 \%$, rather than $90.6 \%$ as shown in the last row of the table.

Table 2.2. Fuels used for FFV evaluations.

\begin{tabular}{|c|c|c|c|c|}
\hline Fuel Property & $\begin{array}{c}\text { ASTM } \\
\text { Method }\end{array}$ & Units & E10 & E30 \\
\hline Carbon & D5291 & wt. \% & 82.74 & 75.04 \\
\hline Hydrogen & D5291 & wt. \% & 13.66 & 13.69 \\
\hline Oxygen & D4815/D5599 & wt. \% & 3.70 & 11.27 \\
\hline density at 15 C & D4052 & g/cc & 0.7517 & 0.7470 \\
\hline Ethanol & D4815/D5599 & vol. \% & 10.0 & 30.58 \\
\hline RON & D2699 & - & 92.4 & 100.7 \\
\hline MON & D2700 & - & 84.1 & 88.0 \\
\hline $\begin{array}{c}\text { Antiknock Index } \\
\text { (RON+MON)/2 }\end{array}$ & N/A & - & 88.2 & 94.4 \\
\hline Lower Heating Value & D240 & MJ/kg & 41.889 & 38.174 \\
\hline RVP & D5191 & psi & 7.2 & 12.9 \\
\hline $\begin{array}{c}\text { Volumetric LHV } \\
\text { (Energy Density) }\end{array}$ & N/A & MJ/liter & 31.49 & 28.52 \\
\hline Energy Density Ratio & N/A & $\begin{array}{c}\text { \% of E10 } \\
\text { fuel }\end{array}$ & $100 \%$ & $90.57 \%$ \\
\hline
\end{tabular}

* LA4 is the first 1372 seconds of the Federal Test Procedure, or the city test. http://www.epa.gov/nvfel/testing/dynamometer.htm\#vehcycles

${ }^{\dagger}$ LA92, also known as the unified cycle, developed as an emissions inventory improvement tool by California Air Resources Board. This cycle has higher top speed, higher average speed, less idle, and harder accelerations than the LA4.

₹ US06 is a high acceleration aggressive driving schedule used for emissions certification 
The WOT experiment sequence is described by the list that follows, and the speed versus time trace is shown in Fig. 2.1.

\section{Description of WOT test sequence}

1. Operate vehicle ( $\sim 55 \mathrm{mph})$ to warm oil to $93 \mathrm{C} / 200^{\circ} \mathrm{F}$

2. 50 mph cruise (5 minutes)

3. 30 mph cruise (1 minute)

4. Idle (1.5 minutes)

5. Wide open throttle acceleration to beyond $80 \mathrm{mph}$

6. Momentary hold at $~ 85 \mathrm{mph}$

7. Deceleration, $30 \mathrm{mph}$ cruise (1 minute) for cool down

8. Repeat steps 4-7 for second WOT acceleration

9. Repeat steps 4-7 for third WOT acceleration

10. Cool down and end test

A speed versus time trace for the WOT test is shown in Figure 2.1, starting with step 2 (figure does not include the pre-test cycle warming of the vehicle engine oil to $200^{\circ} \mathrm{F}$ ).

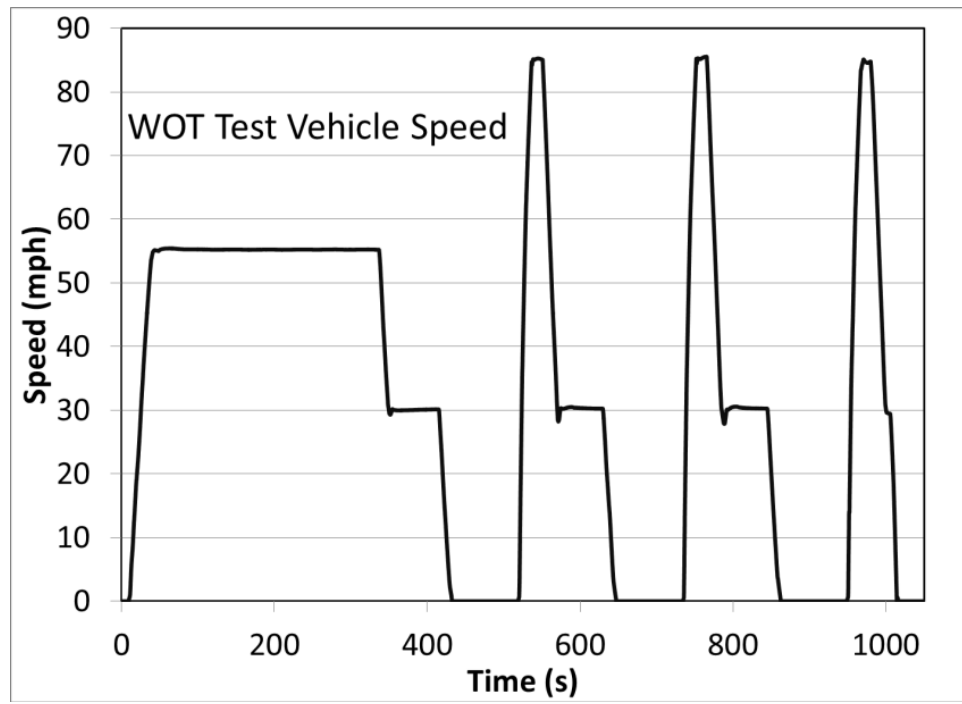

Figure 2.1. Vehicle speed trace for the custom WOT drive cycle. 


\section{FFV EXPERIMENTAL RESULTS}

The primary objective was to obtain WOT acceleration rates for E10 and E30. Consistent acceleration comparisons can be made from measuring the time required to accelerate from a selected lower speed until attaining a selected high speed during WOT. While the automotive press commonly reports $0-60 \mathrm{mph}$ time or $1 / 4$ mile time, consistent vehicle launch is critical to achieving valid comparisons. To minimize launch effects on the vehicle dynamometer, a starting point of 15 mph was chosen as a lower speed to eliminate the driver "tip-in" (initial pressing of accelerator to maximum) portion of each acceleration event. More discussion is included later.

\subsection{EFFECT OF AIR DENSITY AND OXYGEN CONTENT ON MAXIMUM POWER}

The acceleration of a conventional SI powertrain vehicle under WOT conditions is limited by the powertrain module controls (e.g., spark timing, stoichiometry, transmission control) and by the density and oxygen content of the air coming into the engine intake. It was assumed that the vehicle was at fuel-rich or stoichiometric conditions during the WOT acceleration, and particularly during the 15 to 80 mph phase. These fuel-rich conditions can be seen in Fig. 3.1 for a WOT event with the GMC Sierra. For a given fuel, with all other things being equal, the instantaneous power during the WOT event is affected by the amount of air and oxygen that is being inducted into the cylinders.

It can be noted that measured lambda is $>1.0$ during the idle portion in the figure. The engine is not running lean, rather this lambda value is an artifact of the instrumentation setup. To minimize vehicle modifications, the lambda meter was installed near the dilution tunnel in the transfer line from the vehicle, rather than in the vehicle exhaust system. The dilution tunnel was set at a very high flowrate as a precaution to prevent high tunnel temperatures for the WOT tests. Under this high flow condition, at very low exhaust flow rates, such as idle, small air leaks into the exhaust can lead to a large error in lambda. Note that during the cruise portion of the WOT test that the lambda is 1.0 as expected.

All reasonable attempts were made to keep conditions consistent from test-to-test, including cell temperature, engine oil temperature (which correlates with engine coolant temperature) and even soak time between experiments. The repeat of the warm up driving period to obtain $200^{\circ} \mathrm{F}$ oil temperature and the steady cruise portions of the WOT test (Fig. 2.1), resulted in each WOT sequence being very similar to all others. However, small variations in the air humidity and the absolute air pressure in the test cell were unavoidable and did occur.

The ambient test cell air temperature was measured at the discharge side of the vehicle cooling fan (Figure 3.2), which blows air directly into the front of the test vehicle with wind speeds matching wheel speed. This air is of course subsequently inducted by the engine intake. Also measured and recorded were the pressure and humidity of the test cell air. These measurements can be used to calculate the wet air density and dry air density. The dry air density variation from test to test is assumed to be proportional to a subsequent variation of oxygen being drawn into the engine. The engine generally operates fuel-enriched at WOT conditions, as shown in Fig. 3.1 for the GMC Sierra, and therefore oxygen intake will determine how much fuel is burned and how much power is produced. While this assumption may be a simplification, results will show clearly that performance correlates to the dry air density. Partial pressure of oxygen in the combustion chamber is affected by 
the temperature and humidity, as discussed, as well as volumetric efficiency of the engine. The HoV of the fuel can impact volumetric efficiency due to cooling of the intake air. The extent of this phenomenon depends on many factors, among them the injection strategy, such as whether the port fuel injection occurs on a closed or open intake valve. In the case of the DI engines, it is not known how much fuel is injected during the intake stroke versus after the intake valve is closed. The HoV can help improve the volumetric efficiency, or suppress knock by cooling the intake charge, or both.

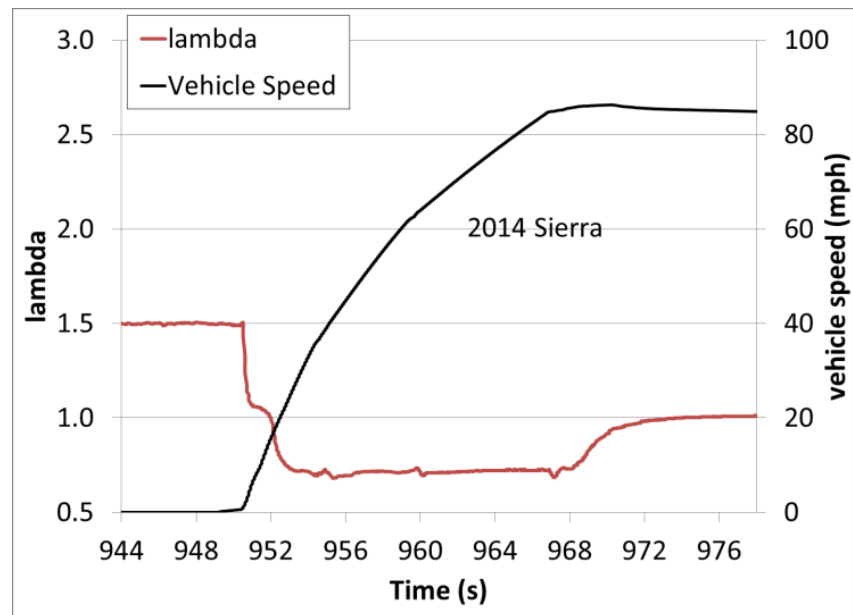

Figure 3.1. Lambda and speed trace during Sierra WOT test. (Lambda $>1.0$ at idle is an artifact of the test setup)

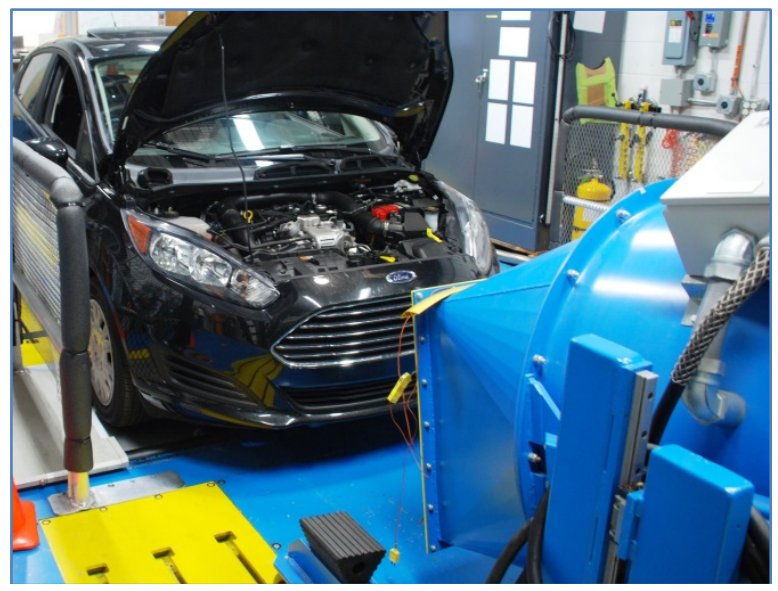

Figure 3.2. Vehicle cooling fan provides cooling air at wheel speed to mimic on-road conditions.

\subsection{WOT PERFORMANCE RESULTS FOR FLEX FUEL VEHICLES.}

The WOT performance was determined by evaluating the acceleration time from a speed of $15 \mathrm{mph}$ to $80 \mathrm{mph}$. A professional driver was used for all tests. The WOT condition was produced by starting from a stopped condition (with the vehicle in drive) and then "tipping-in" the accelerator pedal relatively quickly to full position, but with care to minimize wheel spin relative to the dynamometer roller. A starting point of $15 \mathrm{mph}$ for data analysis was used to ensure that wheel slip or any differences in the driver "tip-in" to full pedal position did not impact the measurement. Data analysis confirmed that the WOT condition was reached before $15 \mathrm{mph}$ in all cases. 


\subsubsection{GDI Vehicles}

Two of the vehicles included in this effort feature naturally-aspirated engines with direct fuel injection. More benefit from charge cooling is expected for GDI compared to PFI.

\subsubsection{2014 GMC Sierra}

Performance improvement for the GMC Sierra WOT acceleration with the higher octane E30 fuel is clearly shown in Fig 3.3. The improvement in $15-80 \mathrm{mph}$ time is about 0.38 seconds for comparable points (values above $1.122 \mathrm{~g} /$ liter air density in the plot) or about 3.0\%. It is seen from Fig. 3.4 that spark timing is advanced 1 or 2 crank angle degrees for part of the WOT event for the E30 fuel compared to the E10 tests. These results are consistent with 0-60 and 1/4 mile times reported in the press for a similarly equipped Chevrolet Silverado FFV fueled with E10 and E85, ' highlighting the non-linear octane-boosting effect of ethanol. ${ }^{\dagger \neq}$ For the GM V6 engine in the Silverado and Sierra, E30 provides a performance boost similar to E85.

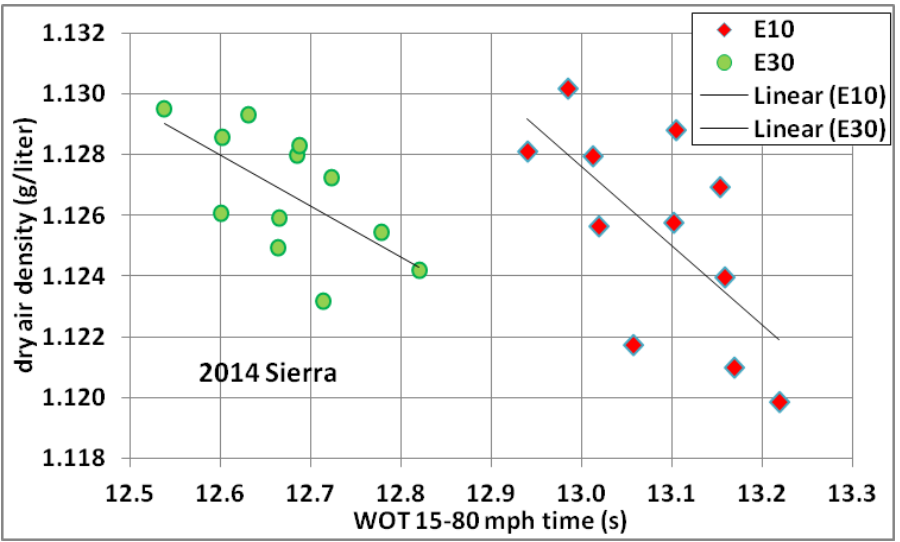

Figure 3.3. The improvement in $15-80 \mathrm{mph}$ acceleration time for using E30 fuels was approximately 0.35-0.50 seconds for the Sierra Truck.

\footnotetext{
* Car and Driver, “Drivelines: Chevrolet Silverado V6,” Vol. 59, No. 9, March 2014, pp. 102-13, also available at http://www.caranddriver.com/reviews/2014-chevrolet-silverado-v-6-instrumented-test-review

† Szybist, J. and West, B., "The Impact of Low Octane Hydrocarbon Blending Streams on the Knock Limit of “E85”," SAE Int. J. Fuels Lubr. 6(1):2013, doi:10.4271/2013-01-0888

‡ Stein, R., Polovina, D., Roth, K., Foster, M. et al., "Effect of Heat of Vaporization, Chemical Octane, and Sensitivity on Knock Limit for Ethanol - Gasoline Blends,” SAE Int. J. Fuels Lubr. 5(2):823-843, 2012, doi:10.4271/2012-01-1277.
} 


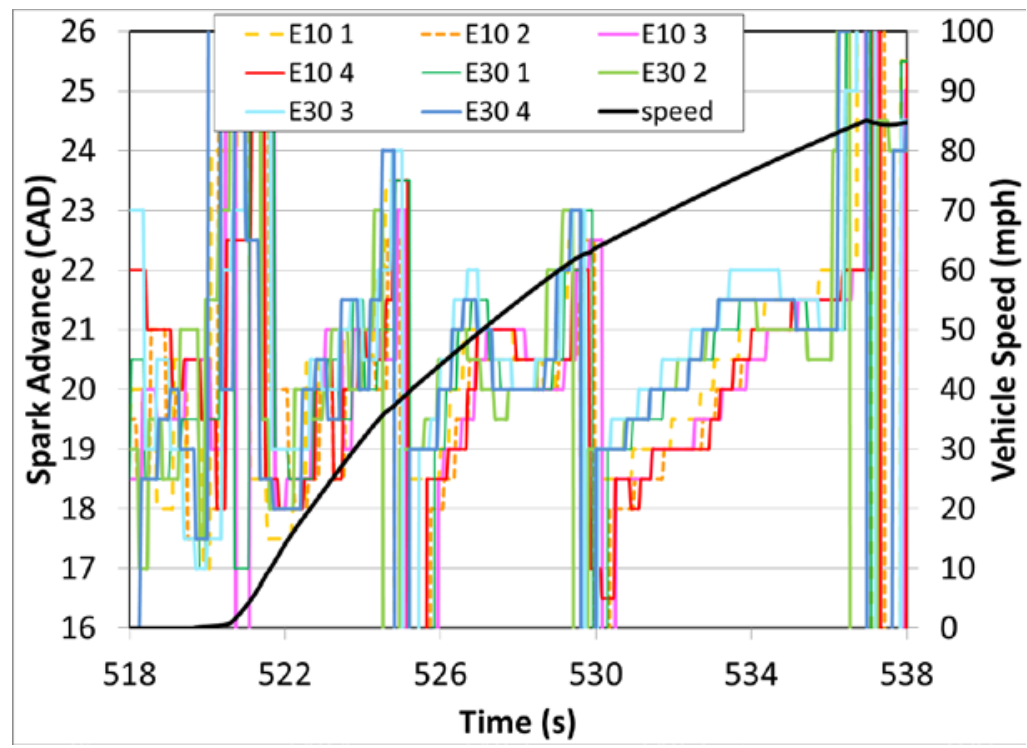

Figure 3.4. Ignition timing for GMC Sierra during WOT acceleration shows higher spark advance for the E30 fuel compared to E10.

\subsubsection{2014 Chevrolet Impala}

Performance improvement for the Chevrolet Impala WOT acceleration for E30 versus E10 fuel is shown in Fig 3.5. The improvement in $15-80 \mathrm{mph}$ acceleration time is about 0.2 to 0.3 seconds for an average of roughly a $2.5 \%$ improvement. It is seen from Fig. 3.6 that spark timing is advanced roughly 2 crank angle degrees for the majority of the WOT event for the E30 fuel compared to the E10 tests. Only one test with each fuel is shown in the Fig. 3.6 due to problems in obtaining the CAN data (including spark timing) on some experiments.

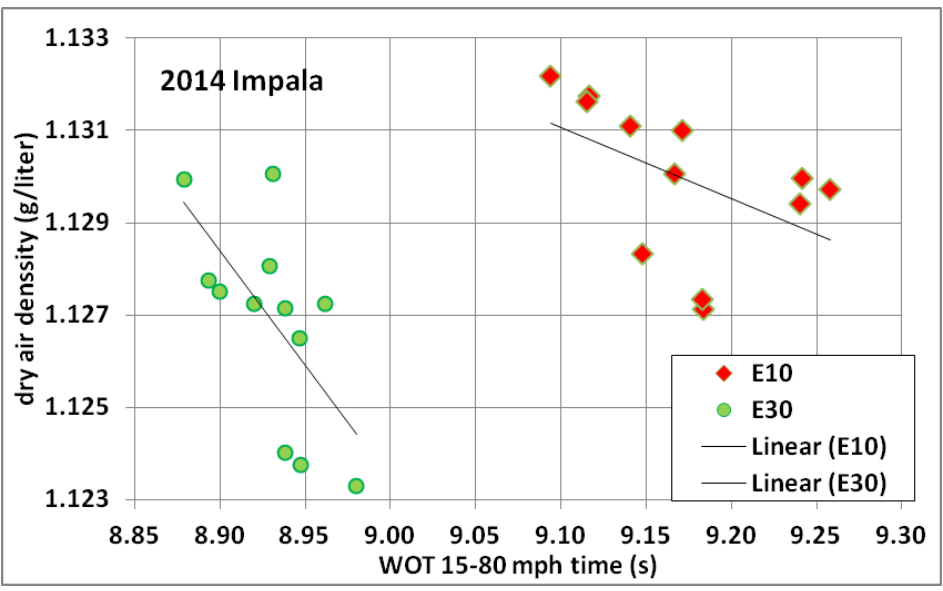

Figure 3.5. The improvement in $15-80 \mathrm{mph}$ acceleration time for using E30 fuels was approximately 0.25 seconds for the Impala sedan. 


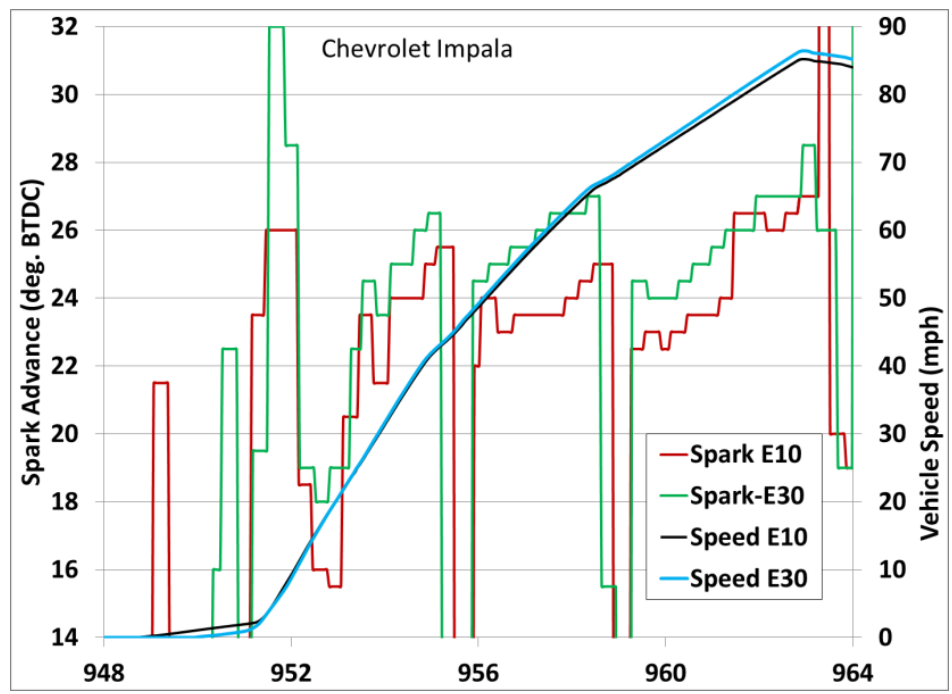

Figure 3.6. Ignition timing for Chevrolet Impala during WOT acceleration show higher spark advance for the E30 fuel compared to E10.

\subsubsection{PFI Vehicles}

The Chrysler and Ford test vehicles were equipped with port-fuel injection.

\subsubsection{2013 Dodge Caravan}

The improvement in 15-80 mph acceleration time for the Caravan using E30 fuel is shown in Figure 3.7. Despite some variation in test conditions, when comparing comparable ambient conditions the E30 WOTs are about 0.20 second faster than the E10 WOT events. This translates into about a 1.7\% improvement in 15-80 mph acceleration time. A small advance in spark timing is seen during part of the WOT acceleration for the E30 fuel compared to E10, as shown in Figure 3.8.

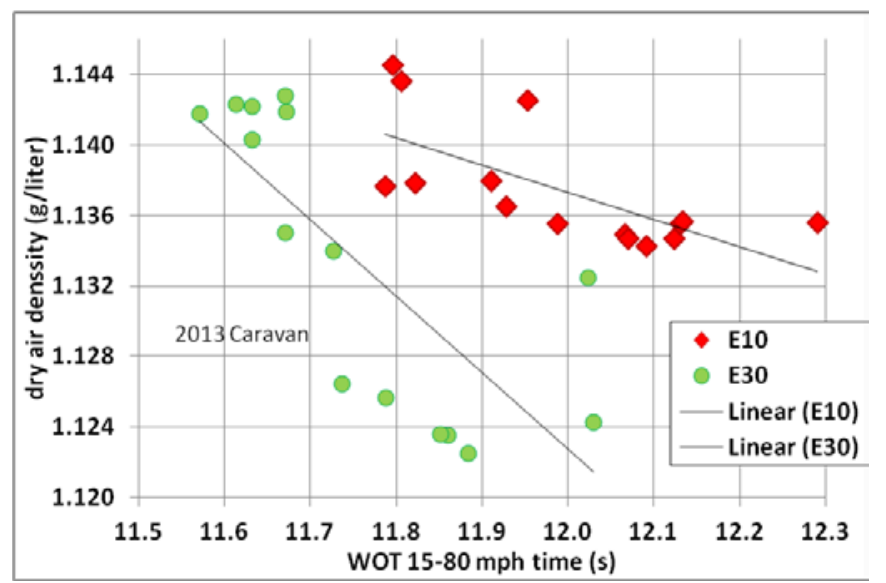

Figure 3.7. The improvement in $\mathbf{1 5 - 8 0} \mathrm{mph}$ acceleration time with high octane E30 fuel was approximately 0.20 seconds or greater for the Caravan. 


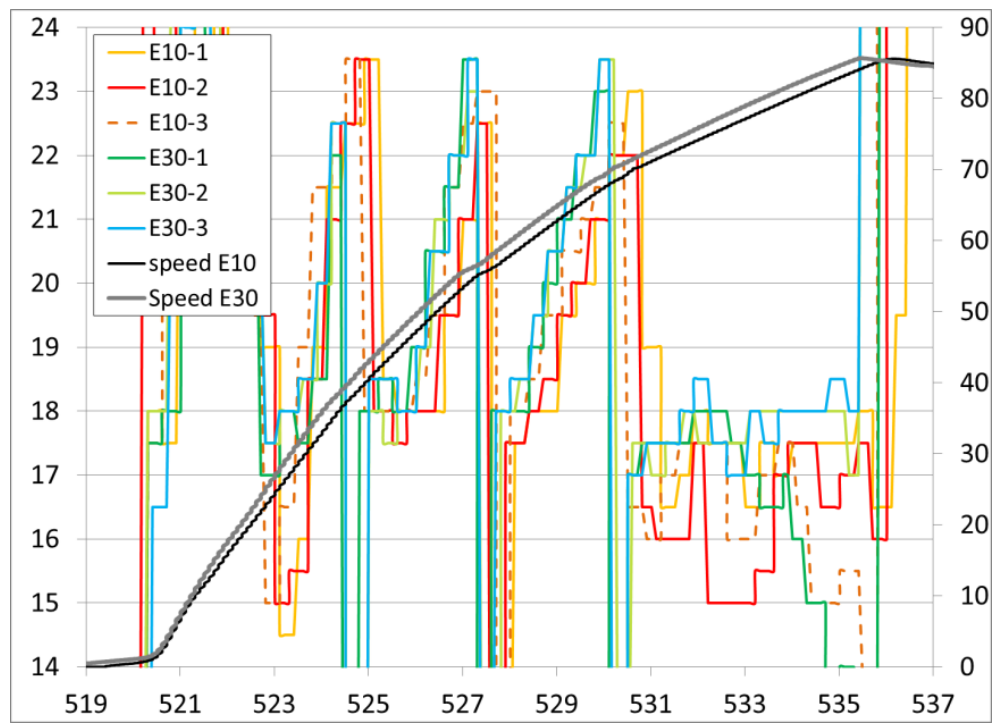

Figure 3.8. Ignition timing for Dodge Caravan during WOT acceleration show evidence of higher spark advance for the E30 fuel compared to E10.

\subsubsection{2013 Ford F150}

The F150 FFV did not exhibit any consistent improvement in WOT performance by fueling with E30. The data shown in Fig. 3.9 shows little difference in the results for the two fuels. Similarly, there was little evidence of any difference in spark timing between the fuels as seen in Fig. 3.10. With this set of experiments it cannot be definitively determined whether the E30 failed to offer any anti-knock benefits at the engine operating condition, or whether the engine controller was unable to adjust to benefit from better anti-knock fuel.

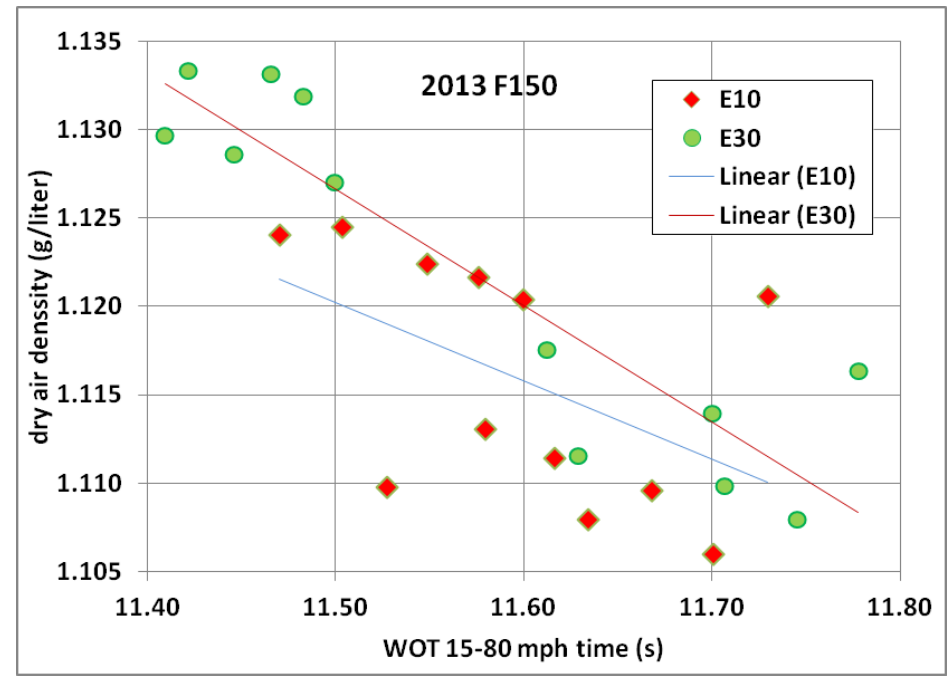

Figure 3.9. No discernable improvement in $15-80 \mathrm{mph}$ acceleration time was observed for using E30 fuel compared to E10 fuel for the F150. 


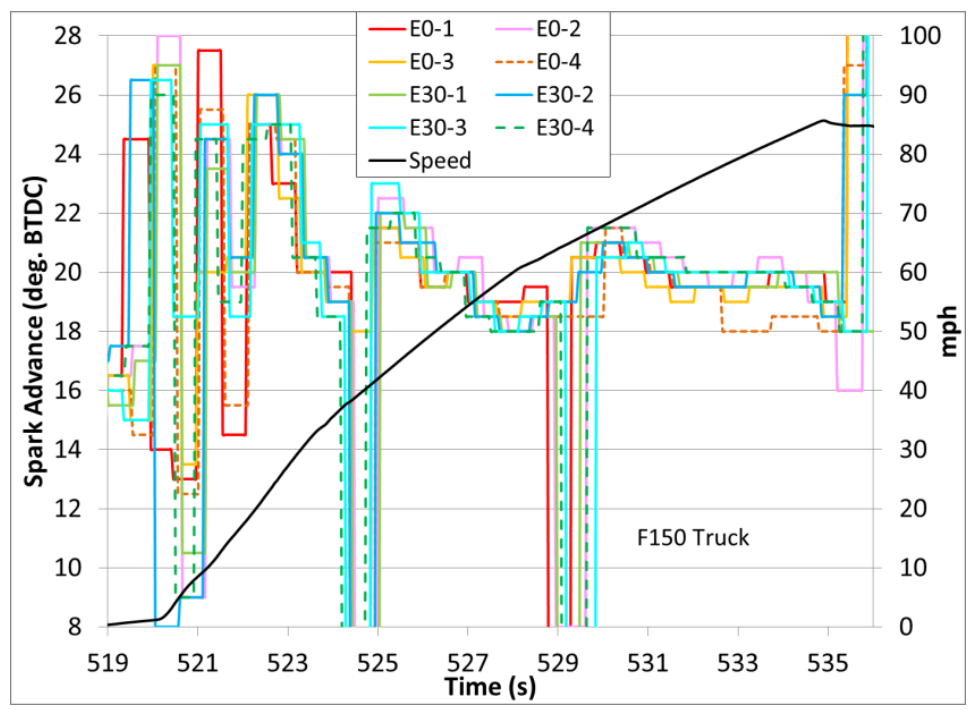

Figure 3.10 Ignition timing for Ford F150 during WOT acceleration show little evidence of higher spark advance for the E30 fuel compared to E10.

\subsection{FFV FUEL ECONOMY RESULTS}

Comparing the E10 fuel to the E30, an expected fuel economy drop of about 9.5\% would be anticipated based on volumetric heating values of the fuels (see Table 2.2). Considering the four vehicles as a whole, the fuel economy penalty for E30 vs. E10 was about 8 to 9\%. The measured fuel economy for each individual test is included in tables presented in the Appendix. The mpg results are given in Figure 3.11, representing the averaged results for each fuel (in most cases this is the average of 2 tests) based on fuel use measured by a Coriolis mass flow meter. Fuel economy was also calculated by the full flow dilution method and carbon mass balance (CMB). Results from CMB and the Coriolis meter are generally within 1\%. The modest thermal efficiency improvement with E30 versus E10 indicates that these vehicles experience little to no knock-limited operation on these two certification cycles.

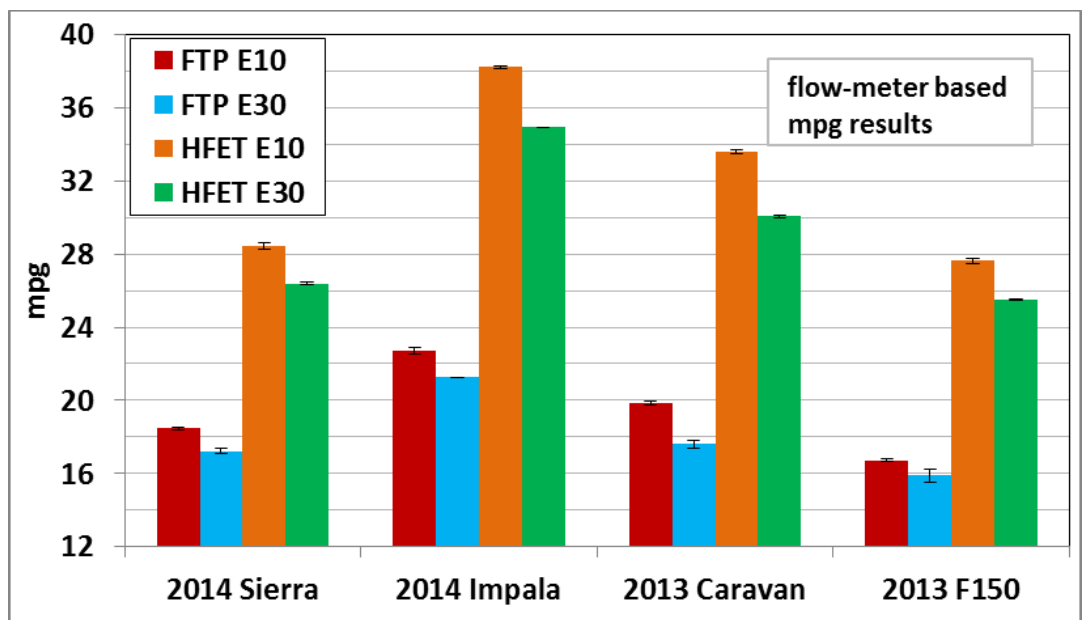

Figure 3.11 Average measured FTP and HFET cycle fuel economy for the FFVs with E10 and E30 fuels. Range bars indicate the maximum and minimum of test values. 


\subsection{FFV EMISSIONS RESULTS}

All four vehicles meet the relevant emission standards (one individual FTP test was outside of its Tier 2 limit for nonmethane organic gas (NMOG) emissions). Nonmethane organic gas emissions were not directly measured, but were estimated from nonmethane hydrocarbon (NMHC) emissions using a method developed during the DOE Intermediate Ethanol Blends Catalyst Durability Program, ${ }^{* \dagger}$ which was subsequently adopted by EPA under the Tier 3 rule. ${ }^{\ddagger}$ As adopted by EPA, the method is only approved for use with blends of up to E25. Given the very linear nature of the relationship, and the fact that this was not an emissions test program, the method was applied here for the E30 blends. No fuel effect trends were observed. Data scatter was noted, which would be expected due to the low levels of emissions (small values being measured) and normal chassis test variation. Emission values for all EPA test cycle experiments are summarized in Tables A.1 to A.5 in the Appendix.

\footnotetext{
* West, Brian H., Scott Sluder, Keith Knoll, John Orban, Jingyu Feng, Intermediate Ethanol Blends Catalyst Durability Program, ORNL/TM-2011/234, February 2012, available at http://info.ornl.gov/sites/publications/Files/Pub31271.pdf

† Sluder, C. and West, B., "NMOG Emissions Characterizations and Estimation for Vehicles Using Ethanol-Blended Fuels," SAE Int. J. Fuels Lubr. 5(2):721-732, 2012, doi:10.4271/2012-01-0883

${ }^{\ddagger}$ Federal Register, Vol. 79(81), Monday, April 28, 2014, “Control of Air Pollution From Motor Vehicles: Tier 3 Motor Vehicle Emission and Fuel Standards,” Final Rule.
} 


\section{2014 FORD FIESTA ECOBOOST EXPERIMENTS}

A 2014 Ford Fiesta SFE equipped with the 1.0 liter, 3-cylinder turbocharged, direct-injection engine was acquired (14,200 mi. odometer reading). The Fiesta is not an FFV, but it is warranted to use E15, and the owner's manual notes that while regular 87 octane fuel is recommended, the use of premium fuel will provide improved performance and is recommended for severe duty usage.

\subsection{TEST SEQUENCE AND FUELS}

Instrumentation for the Fiesta was the same as for the FFV vehicles (see sections 2.3 and 2.4). The high-load, high speed US06 cycle was added as an additional test for this vehicle. Like the highway test, the US06 is conducted as a "double" test in which the cycle is run twice in succession (with 90 seconds of idle in between), the first test and the idle portion make up the preparatory cycle; only the second US06 cycle results are used for calculating emissions and fuel economy. Because the Fiesta is equipped with a manual transmission, the WOT test was executed in a different manner than that for the FFVs; the WOT protocol is described later.

Fuel properties are given in Table 4.1. The E0 is a commercially available retail gasoline provided by Corrigan Oil. Reagent-grade 200-proof ethanol was splashed-blended into this same E0 to produce the E15. Fuel analyses were provided by Southwest Research Institute.

Table 4.1. Fuels used for the Ford Fiesta evaluations.

\begin{tabular}{|c|c|c|c|c|}
\hline Fuel Property & $\begin{array}{c}\text { ASTM } \\
\text { Method }\end{array}$ & Units & E0 & $\begin{array}{c}\text { E15 } \\
\text { (blended from E0) }\end{array}$ \\
\hline Carbon & D5291 & wt. \% & 85.97 & 80.21 \\
\hline Hydrogen & D5291 & wt. \% & 14.62 & 14.24 \\
\hline Oxygen & D5599 & wt. \% & $<0.10$ & 5.93 \\
\hline density at 15C & D4052 & g/cc & 0.7153 & 0.7259 \\
\hline Ethanol & D5599 & vol. \% & $<0.10$ & 15.64 \\
\hline RON & D2699 & - & 90.7 & 97.8 \\
\hline MON & D2700 & - & 84.6 & 87.4 \\
\hline $\begin{array}{c}\text { Antiknock Index } \\
\text { (RON+MON)/2 }\end{array}$ & N/A & - & 87.4 & 92.6 \\
\hline Lower Heating Value & D240 & MJ/kg & 44.073 & 41.017 \\
\hline RVP & D5191 & psi & 13.66 & 14.06 \\
\hline $\begin{array}{c}\text { Volumetric LHV } \\
\text { (Energy Density) }\end{array}$ & N/A & MJ/liter & 31.525 & 29.774 \\
\hline Energy Density Ratio & N/A & $\begin{array}{c}\text { \% of E0 } \\
\text { base fuel }\end{array}$ & $100 \%$ & $94.4 \%$ \\
\hline
\end{tabular}

* 2014 Ford Fiesta Owner's Manual, March 2013, available at: http://owner.ford.com/servlet/ContentServer?pagename=Owner/Page/OwnerGuidePage\&year=2014\&make=Ford\&model= Fiesta 
The daily test sequence is listed as follows:

1. Cold city test also known as the FTP

2. 20 minute soak,

3. Highway fuel economy test (HFET),

4. 20 minute soak,

5. US06 test,

6. Vehicle warmup (50 mph cruise, bring oil to $93 \mathrm{C} / 200^{\circ} \mathrm{F}$

7. Custom WOT test cycle (4 back-to-back WOTs)

In addition to 4 days of the test cycles listed above being performed (2 each with a given fuel), an additional FTP, HFET and US06 was performed with each fuel resulting in triplicate results for the drive cycle tests.

\subsection{WIDE OPEN THROTTLE EXPERIMENTS}

The experimental protocol for the Fiesta was similar to that used for the FFV vehicles, with the following exceptions

1) Four WOT acceleration events were performed in each test in the manner shown in Fig 4.1

2) Due to the manual transmission, the driver shifted 2 times before reaching $30 \mathrm{mph}$ and held the accelerator pedal (to the floor) for maximum acceleration while in third gear until reaching $93 \mathrm{mph}$. Thus a "fixed gear WOT test" was performed from 30 to $90 \mathrm{mph}$ to mitigate wheel slip and eliminate variability in shift times.

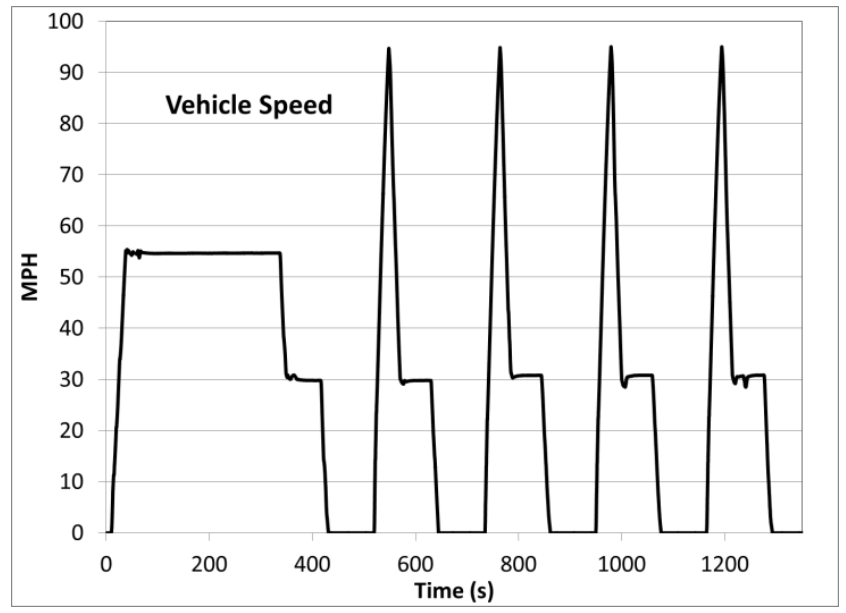

Figure 4.1 Vehicle speed trace for the custom Fiesta WOT drive cycle. 


\subsection{RESULTS}

\subsubsection{Wide Open Throttle Acceleration}

A very obvious improvement in fixed-gear WOT acceleration is seen when E0 results are compared with E15 results; acceleration times from 30 to $90 \mathrm{mph}$ improve by about 1.0 second, as shown in Fig. 4.2. Spark advance increase is also measured for the E15 fuel as seen in Fig. 4.3, with a difference of over 5 degrees observed for a segment of the test.

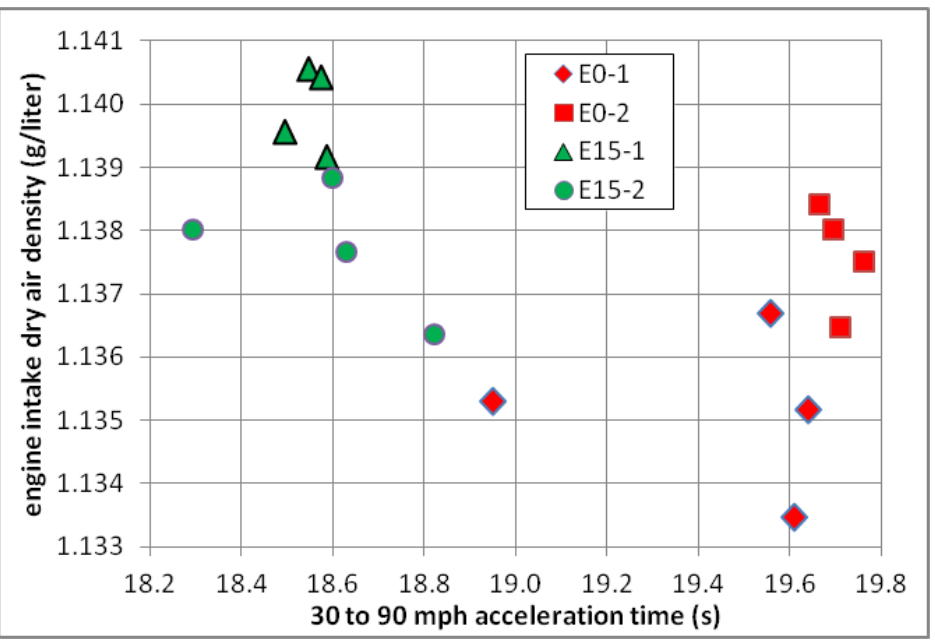

Figure 4.2 Fixed-gear WOT 30 to $90 \mathrm{mph}$ acceleration times for the Ford Fiesta.

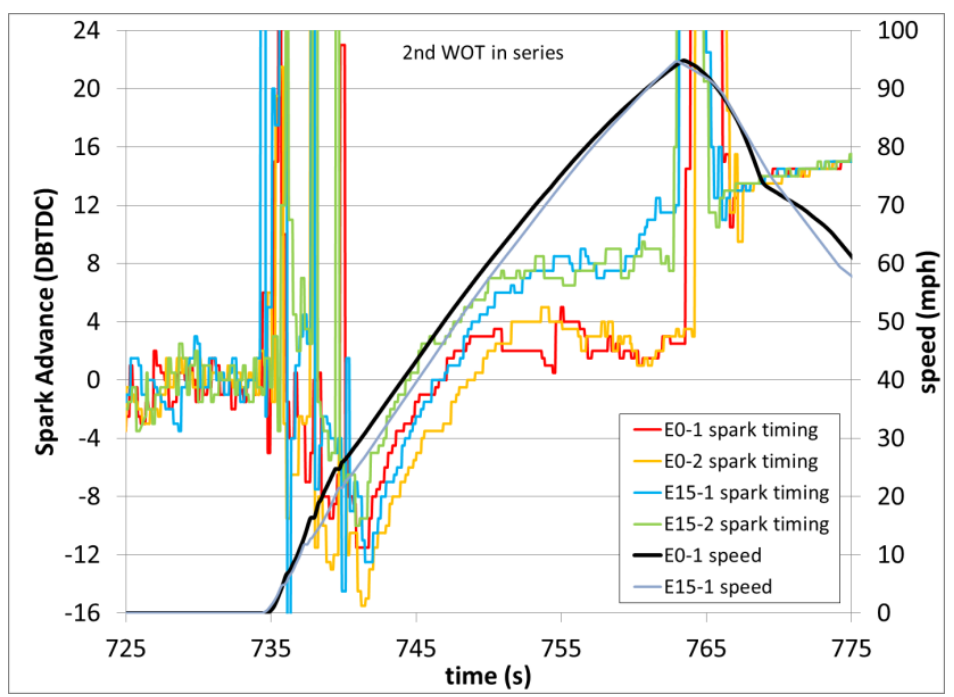

Figure 4.3 Ignition timing for the Ford Fiesta shows greater WOT spark advance for highoctane E15 vs. E0.

\subsubsection{EPA Test Cycles and Fuel Economy}

The results of FTP, HFET and US06 test cycles indicate an improvement in thermal efficiency with the high-octane E15 fuel. Figure 4.4 gives results in mpg for the test cycles (also see Appendix tables). Figures 4.5 and 4.6 compare E15 fuel economy on a relative basis to E0, to highlight the 
improved efficiency for high-octane E15, despite the lower heating value. The expected drop in mpg is 5.6\% for E15 versus E0 (based on volumetric energy density ratio), but the E15 fuel economy is considerably higher for all tests. (Two separate methods were used to measure fuel economy, one is the dilution tunnel carbon-balance method required by the CFR for EPA cycle testing, and the second method is by a Coriolis mass flowmeter measuring fuel flow into the engine). For the US06 cycle, volumetric fuel economy parity is almost realized with E15, indicating a $4.6 \%$ improvement in thermal efficiency. These results are due to the apparent knock-limited operation on the high load US06 cycle (versus the FTP and HFET). High octane fuel enables less spark retard and significantly improved efficiency. These results are consistent with those reported by others with turbocharged, direct-injection engines. ${ }^{* \dagger}$ It is worthwhile to note that the energy density difference between E0 and E15 is very similar to that expected between E10 and E25. It is also important to note that no changes were made to the Fiesta shift schedule. Hardware and software changes to future vehicles using highoctane mid-level blends would be expected to enable greater efficiency gains from downspeeding.

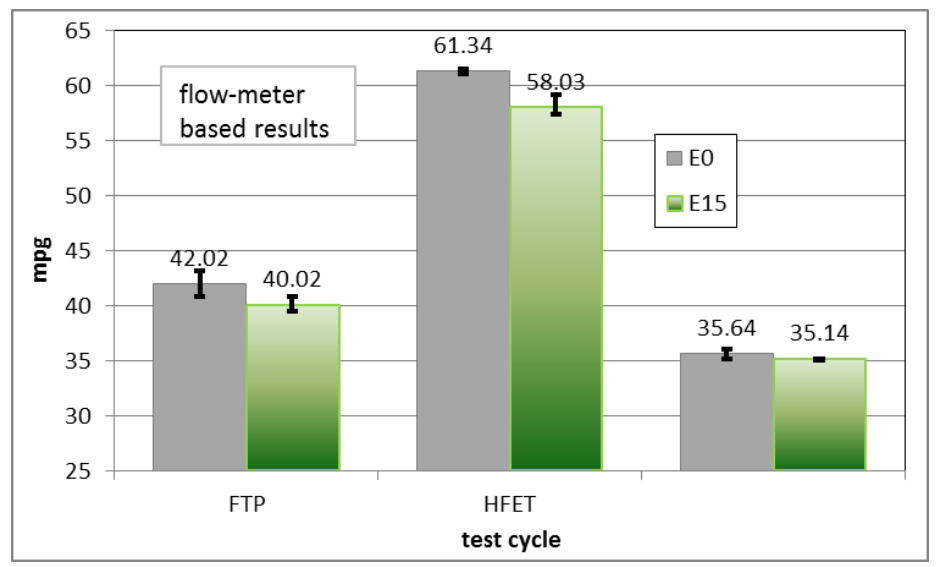

Figure 4.4 Fiesta fuel economy with E0 and E15 fuels. The bars indicate average fuel economy for each test cycle, range bars indicate the maximum and minimum values.

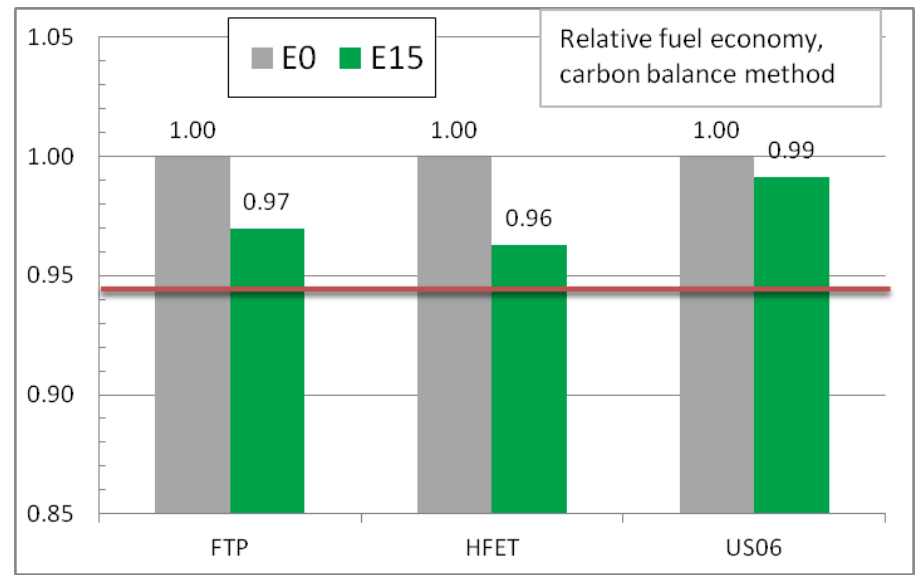

Figure 4.5 Relative fuel economy for the E0 and E15 fuels, based on carbon balance calculations. The red line indicates the expected fuel economy with E15 based on the volumetric heating value ratio of the fuels.

\footnotetext{
* Jung, H., Leone, T., Shelby, M., Anderson, J. et al., "Fuel Economy and $\mathrm{CO}_{2}$ Emissions of Ethanol-Gasoline Blends in a Turbocharged DI Engine," SAE Int. J. Engines 6(1):422-434, 2013, doi:10.4271/2013-01-1321

${ }^{\dagger}$ Leone, T., Olin, E., Anderson, J., Jung, H. et al., "Effects of Fuel Octane Rating and Ethanol Content on Knock, Fuel Economy, and $\mathrm{CO}_{2}$ for a Turbocharged DI Engine," SAE Int. J. Fuels Lubr. 7(1):9-28, 2014, doi:10.4271/2014-01-1228
} 


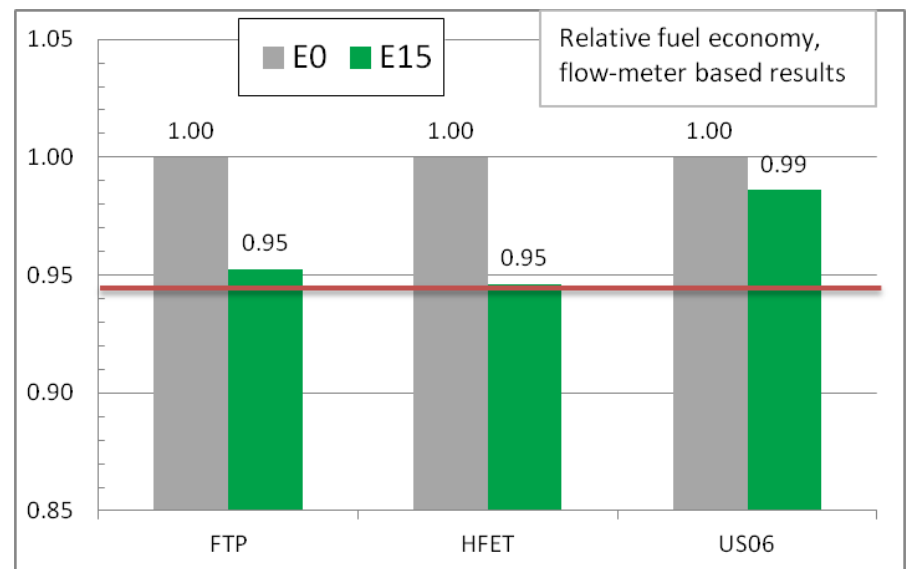

Figure 4.6 Relative fuel economy for the E0 and E15 fuels, based on fuel flow measurements (into the engine). The red line indicates the expected fuel economy with E15 based on the volumetric heating value ratio of the fuels.

Spark timing changes were also evident for the US06 cycle during hard accelerations (where knocklimited behavior would be expected). An example is shown in Fig. 4.7.

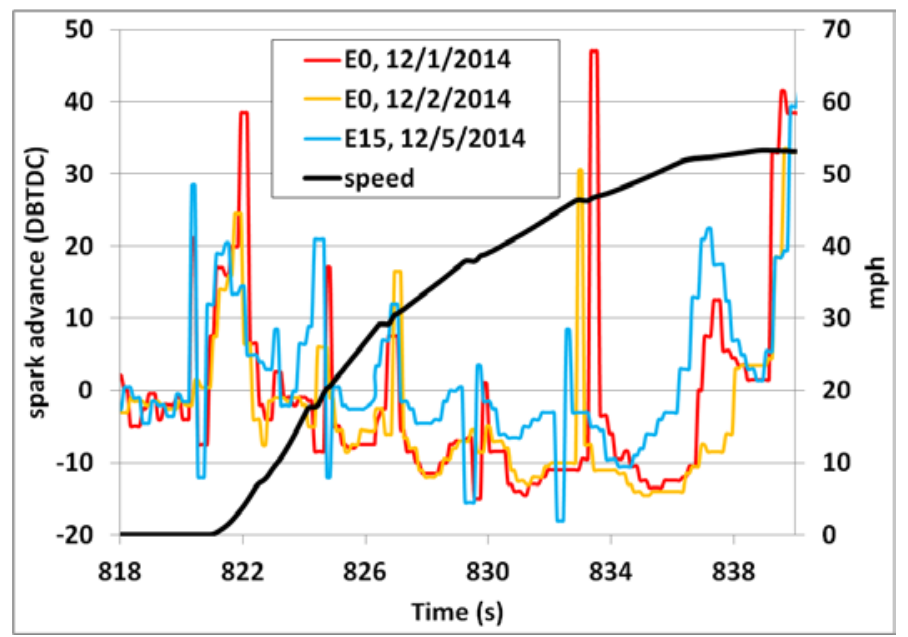

Figure 4.7 Ford Fiesta spark timing during a US06 cycle acceleration. In some cases the ignition timing is 5-10 degrees more advanced for the high-octane E15 fuel compared to the E0 fuel.

\subsubsection{Emissions}

Emissions data were collected for the FTP, HFET and US06 cycles using the standard full-flow dilution tunnel, constant volume sampling bag method. Emission values for all EPA test cycle based experiments are presented in Tables A6, A7 and A8 in the Appendix. With the exception of a few potential noncompliances on NMOG, all emissions were within the required Tier 2 limits for this vehicle, and no notable fuel effects were noted. 


\section{SUMMARY AND CONCLUSIONS}

Experiments were performed with four normally-aspirated, late-model FFVs using a certification E10 fuel (92.4 RON) and a splash blend E30 (100.7 RON) produced from a retail fuel. Two of the FFVs were equipped with direct-injection engines, and two were equipped with port fuel injection.

- The two GDI FFVs demonstrated performance improvements for E30 compared to E10 of 0.3 to 0.4 seconds, or 2.5 to $3 \%$, based on the $15-80 \mathrm{mph}$ WOT acceleration time.

- The two PFI FFVs yielded mixed results with one vehicle demonstrating a 0.2 second, or $1.7 \%$, performance improvement and another showing no improvement for E30 vs. E10 based on the 15-80 mph WOT acceleration time.

- Fuel economy on the light load FTP and HFET changed largely in proportion to the volumetric heating value of the fuels (within roughly 1-2\%), indicating insignificant knock limited operation with the base E10 fuel.

- $\quad$ No notable emissions changes were observed due to switching fuels.

Three of the four tested FFVs showed performance improvement with high-octane E30 compared to regular E10. The performance improvement of the GMC Sierra with E30 is similar to published performance tests with E85. Marketing E25 or E30 to FFV owners as a performance fuel may enable greater ethanol utilization in the near term, and could help establish the refueling infrastructure to enable manufacturers to build dedicated vehicles designed for a high-octane midlevel ethanol blend.

A non-flex fuel vehicle with a small turbocharged GDI engine was tested with an ethanol-free regular grade gasoline and a splash blend of this same fuel with $15 \%$ ethanol by volume. RON was increased from 90.7 for the E0 to 97.8 for the E15 blend.

- Significant WOT performance improvement was measured for this vehicle. Using a fixedgear 30 to $90 \mathrm{mph}$ acceleration time metric, a 1.0 second, or 5\%, improvement was seen for the E15 fuel.

- Thermal efficiency was improved using the E15 fuel on all test cycles, most significantly on the high-load US06 cycle. The US06 results showed a 4.6\% thermal efficiency improvement with only $1 \%$ lower miles per gallon using the E15, despite a $5.6 \%$ lower energy density. A thermal efficiency improvement of 1-3\% was observed on the lighter load FTP and HFET cycles.

- $\quad$ No notable emissions changes were observed due to switching fuels.

For the turbocharged GDI Fiesta vehicle with high-octane E15, the results on the US06 are indicative of what could be achieved with state-of-the-art downsized, downsped engines on the FTP and HFET. This engine technology represents a rapidly growing segment of new vehicle sales, and has significant potential for increased efficiency with high-octane fuels. Achieving within $1 \%$ of volumetric fuel economy parity on the US06 with E15 compared to E0 is representative of what could be expected in forthcoming vehicles with high octane E25 in comparison with more conventional vehicles using E10. 


\section{RECOMMENDATIONS FOR FUTURE WORK}

Follow-on vehicle studies could investigate the benefits of lower incidence of protective enrichment with ethanol blends in FFVs. Many FFVs are trucks and SUVs, and are used in high-load applications such as trailer towing. When engines are put under severe load they often use programmed fuel enrichment to protect the engine and catalyst system, leading to increased emissions and 10-20\% lower fuel economy. ${ }^{*}$ With an ethanol blend there are very likely engine conditions that would require rich operation with 87 AKI E0 or E10, but could maintain the cleaner, more efficient stoichiometric condition with the higher-octane ethanol blend. The fuel economy advantage in this severe duty situation could be significant, despite the lower energy density of the ethanol blend.

A market study could be conducted to gage consumer interest in choosing a high-octane mid-level blend for their FFV, by promoting attributes such as the performance benefits and the fuel economy advantage over E85.

\footnotetext{
* Knoll, Keith, Brian West, Wendy Clark, Ronald Graves, John Orban, Steve Przesmitzki, Timothy Theiss, Effects of Intermediate Ethanol Blends on Legacy Vehicles and Small Non-Road Engines, Report 1-Updated, NREL/TP-54043543/ORNL/TM-2008/117, February 2009.
} 


\section{APPENDIX A. TABULATED EMISSIONS RESULTS}

Emissions summary tables are included for all FTP and HFET cycles for all 5 vehicles, and the Fiesta US06 cycles. Note that the third HFET test with the Fiesta using E15 was performed without the dilution tunnel, but the Coriolis meter-based fuel economy is included in the table. These results are provided for completeness; there are no notable observations in the emissions data. Note that the vehicles are designed to use the relevant test fuels in each case. With the exception of a few potential noncompliances for NMOG, all FTP tests appear to meet the applicable Tier 2 emissions standards.

Table A.1 2014 Sierra FTP and HFET cycle emission results

\begin{tabular}{|l|c|c|c|c|c|c|c|c|}
\hline 2014 Sierra FTP cycle emissions (g/mile) & \multicolumn{4}{|c|}{ HFET cycle emissions (g/mile) } \\
\hline Fuel type & E10 & E10 & E30 & E30 & E10 & E10 & E30 & E30 \\
\hline Test day & 3 & 4 & 1 & 2 & 3 & 4 & 1 & 2 \\
\hline Species & & & & & & & & \\
\hline CO & 0.572 & 0.498 & 0.820 & 0.600 & 0.073 & 0.061 & 0.063 & 0.060 \\
\hline CO2 & 472.6 & 479.0 & 465.8 & 472.3 & 293.0 & 307.6 & 299.4 & 301.5 \\
\hline NOx & 0.0086 & 0.0081 & 0.0087 & 0.0095 & 0.0024 & 0.0022 & 0.0023 & 0.0027 \\
\hline THC & 0.0678 & 0.0631 & 0.0701 & 0.0714 & 0.0031 & 0.0025 & 0.0042 & 0.0052 \\
\hline CH4 & 0.0125 & 0.0122 & 0.0158 & 0.0133 & 0.0000 & 0.0000 & 0.0008 & 0.0007 \\
\hline NMHC & 0.0553 & 0.0509 & 0.0543 & 0.0581 & 0.0031 & 0.0025 & 0.0034 & 0.0045 \\
\hline NMOG & 0.0609 & 0.0561 & 0.0675 & 0.0722 & 0.0034 & 0.0028 & 0.0042 & 0.0056 \\
\hline \multicolumn{7}{|c|}{ Fuel economy (mpg) } & \multicolumn{7}{|c|}{ Fuel economy (mpg) } \\
\hline C-balance & 18.23 & 17.99 & 16.64 & 16.43 & 29.47 & 28.06 & 25.96 & 25.78 \\
\hline Coriolis meter & 18.56 & 18.36 & 17.39 & 17.05 & 28.34 & 28.54 & 26.46 & 26.31 \\
\hline
\end{tabular}

Table A.2 2014 Impala FTP and HFET cycle emission results

\begin{tabular}{|l|c|c|c|c|c|c|c|c|}
\hline 2014 Impala FTP cycle emissions (g/mile) & \multicolumn{4}{|c|}{ HFET cycle emissions (g/mile) } \\
\hline Fuel type & E10 & E10 & E30 & E30 & E10 & E10 & E30 & E30 \\
\hline Test day & 1 & 2 & 3 & 4 & 1 & 2 & 3 & 4 \\
\hline Species & & & & & & & & \\
\hline CO & 0.724 & 0.373 & 0.341 & 0.537 & 0.048 & 0.045 & 0.021 & 0.038 \\
\hline CO2 & 387.3 & 385.5 & 378.0 & 376.2 & 229.5 & 226.6 & 230.1 & 226.1 \\
\hline NOx & 0.0032 & 0.0018 & 0.0039 & 0.0023 & 0.0012 & 0.0012 & 0.0020 & 0.0012 \\
\hline THC & 0.0334 & 0.0234 & 0.0274 & 0.0322 & 0.0014 & 0.0051 & 0.0057 & 0.0051 \\
\hline CH4 & 0.0064 & 0.0051 & 0.0109 & 0.0036 & 0.0016 & 0.0024 & 0.0000 & 0.0024 \\
\hline NMHC & 0.0277 & 0.0191 & 0.0165 & 0.0287 & 0.0000 & 0.0027 & 0.0057 & 0.0028 \\
\hline NMOG & 0.0305 & 0.0210 & 0.0205 & 0.0357 & 0.0000 & 0.0030 & 0.0071 & 0.0035 \\
\hline \multicolumn{7}{|c|}{ Fuel economy (mpg) } & \multicolumn{6}{|c|}{ Fuel economy (mpg) } \\
\hline C-balance & 22.23 & 22.37 & 20.54 & 20.62 & 37.62 & 38.09 & 33.78 & 34.39 \\
\hline Coriolis meter & 22.59 & 22.85 & 21.25 & 21.25 & 37.97 & 38.45 & 34.53 & 35.29 \\
\hline
\end{tabular}


Table A.3 2013 Caravan FTP cycle emission results

\begin{tabular}{|l|c|c|c|c|c|}
\hline 2013 Caravan FTP cycle emissions (g/mile) \\
\hline Fuel type & E10 & E10 & E30 & E30 & E30 \\
\hline Test day & 1 & 2 & 3 & 4 & 5 \\
\hline Species & & & & & \\
\hline CO & 0.496 & 0.472 & 0.723 & 0.526 & 0.531 \\
\hline CO2 & 456.5 & 457.1 & 453.8 & 452.8 & 455.3 \\
\hline NOx & 0.0127 & 0.0098 & 0.0111 & 0.0100 & 0.0093 \\
\hline THC & 0.0403 & 0.0459 & 0.0560 & 0.0392 & 0.0571 \\
\hline CH4 & 0.0072 & 0.0096 & 0.0105 & 0.0175 & 0.0159 \\
\hline NMHC & 0.0330 & 0.0363 & 0.0456 & 0.0287 & 0.0412 \\
\hline NMOG & 0.0363 & 0.0400 & 0.0567 & 0.0357 & 0.0512 \\
\hline \multicolumn{7}{|c|}{ Fuel economy (mpg) } \\
\hline C-balance & 18.88 & 18.86 & 17.09 & 17.14 & 17.04 \\
\hline Coriolis meter & 20.06 & 19.69 & 17.57 & 17.52 & 17.74 \\
\hline
\end{tabular}

Table A.4 2013 Caravan HFET cycle emission results

\begin{tabular}{|l|c|c|c|c|}
\hline 2013 Caravan HFET cycle emissions (g/mile) \\
\hline Fuel type & E10 & E10 & E30 & E30 \\
\hline Test day & 1 & 2 & 3 & 4 \\
\hline Species & & & & \\
\hline CO & 0.248 & 0.171 & 0.315 & 0.293 \\
\hline CO2 & 273.9 & 272.8 & 268.6 & 267.5 \\
\hline NOx & 0.0039 & 0.0038 & 0.0042 & 0.0046 \\
\hline THC & 0.0077 & 0.0097 & 0.0140 & 0.0182 \\
\hline CH4 & 0.0016 & 0.0028 & 0.0036 & 0.0059 \\
\hline NMHC & 0.0062 & 0.0070 & 0.0104 & 0.0123 \\
\hline NMOG & 0.0068 & 0.0077 & 0.0129 & 0.0153 \\
\hline \multicolumn{5}{|c|}{ Fuel economy (mpg) } \\
\hline C-balance & 31.48 & 31.62 & 28.90 & 29.01 \\
\hline Coriolis meter & 33.50 & 33.68 & 29.92 & 30.22 \\
\hline
\end{tabular}

Table A.5 2013 F150 FTP and HFET cycle emission results

\begin{tabular}{|l|c|c|c|c|c|c|c|c|}
\hline \multicolumn{7}{|l|}{2013 F150 FTP cycle emissions (g/mile) } & \multicolumn{3}{|c|}{ HFET cycle emissions (g/mile) } \\
\hline Fuel type & E10 & E10 & E30 & E30 & E10 & E10 & E30 & E30 \\
\hline Test day & 1 & 2 & 3 & 4 & 1 & 2 & 3 & 4 \\
\hline Species & & & & & & & & \\
\hline CO & 0.893 & 0.625 & 0.408 & 0.412 & 0.087 & 0.121 & 0.102 & 0.093 \\
\hline CO2 & 522.5 & 521.7 & 516.2 & 511.6 & 319.0 & 321.6 & 316.8 & 320.3 \\
\hline NOx & 0.0086 & 0.0085 & 0.0065 & 0.0048 & 0.0030 & 0.0018 & 0.0022 & 0.0021 \\
\hline THC & 0.0647 & 0.0904 & 0.0445 & 0.0376 & 0.0030 & 0.0011 & 0.0014 & 0.0003 \\
\hline CH4 & 0.0098 & 0.0100 & 0.0080 & 0.0070 & 0.0023 & 0.0007 & 0.0009 & 0.0000 \\
\hline NMHC & 0.0549 & 0.0809 & 0.0373 & 0.0306 & 0.0007 & 0.0004 & 0.0005 & 0.0003 \\
\hline NMOG & 0.0605 & 0.0891 & 0.0464 & 0.0380 & 0.0008 & 0.0004 & 0.0006 & 0.0004 \\
\hline \multicolumn{7}{|c|}{ Fuel economy (mpg) } & & \multicolumn{5}{c|}{ Fuel economy (mpg) } \\
\hline C-balance & 16.48 & 16.51 & 15.04 & 15.18 & 27.06 & 26.84 & 24.54 & 24.27 \\
\hline $\begin{array}{l}\text { Coriolis } \\
\text { meter }\end{array}$ & 16.81 & 16.66 & 15.87 & 15.90 & 27.70 & 27.57 & 25.57 & 25.46 \\
\hline
\end{tabular}


Table A.6 2014 Ford Fiesta FTP cycle emission results

\begin{tabular}{|l|c|c|c|c|c|c|}
\hline 2014 Ford Fiesta 1.0L FTP cycle emissions (g/mile) & \\
\hline Fuel type & E10 & E10 & E10 & E15 & E15 & E15 \\
\hline Test day & 1 & 2 & 3 & 4 & 5 & 7 \\
\hline Species & & & & & & \\
\hline CO & 1.190 & 1.392 & 1.589 & 0.926 & 1.305 & 1.442 \\
\hline CO2 & 211.8 & 206.6 & 209.8 & 208.7 & 204.3 & 202.5 \\
\hline NOx & 0.0250 & 0.0176 & 0.0190 & 0.0227 & 0.0207 & 0.0204 \\
\hline THC & 0.1643 & 0.1293 & 0.1711 & 0.1198 & 0.1100 & 0.1368 \\
\hline CH4 & 0.0082 & 0.0108 & 0.0118 & 0.0082 & 0.0093 & 0.0092 \\
\hline NMHC & 0.1560 & 0.1184 & 0.1594 & 0.1115 & 0.1008 & 0.1276 \\
\hline NMOG & 0.1718 & 0.1304 & 0.1755 & 0.1267 & 0.1146 & 0.1450 \\
\hline \multicolumn{7}{|c|}{ Fuel economy (mpg) } \\
\hline C-balance & 39.61 & 40.54 & 39.85 & 38.22 & 38.93 & 39.22 \\
\hline Coriolis meter & 40.93 & 43.17 & 41.96 & 39.20 & 40.33 & 40.54 \\
\hline
\end{tabular}

Table A.7 2014 Ford Fiesta HFET cycle emission results

\begin{tabular}{|l|c|c|c|c|c|}
\hline 2014 Ford Fiesta 1.0L HFET cycle emissions (g/mile) \\
\hline Fuel type & E10 & E10 & E15 & E15 & E15 \\
\hline Test day & 2 & 3 & 4 & 5 & 6 \\
\hline Species & & & & & \\
\hline CO & 0.328 & 0.620 & 0.272 & 0.202 & No data \\
\hline CO2 & 144.5 & 143.3 & 142.8 & 141.4 & No data \\
\hline NOx & 0.0073 & 0.0084 & 0.0042 & 0.0019 & No data \\
\hline THC & 0.0075 & 0.0070 & 0.0040 & 0.0027 & No data \\
\hline CH4 & 0.0015 & 0.0030 & 0.0030 & 0.0002 & No data \\
\hline NMHC & 0.0059 & 0.0040 & 0.0010 & 0.0025 & No data \\
\hline NMOG & 0.0065 & 0.0044 & 0.0011 & 0.0028 & No data \\
\hline \multicolumn{7}{|c|}{ Fuel economy (mpg) } \\
\hline C-balance & 58.49 & 58.79 & 56.15 & 56.77 & No data \\
\hline $\begin{array}{l}\text { Coriolis } \\
\text { meter }\end{array}$ & 61.14 & 61.55 & 56.85 & 58.57 & 58.66 \\
\hline
\end{tabular}

Table A.8 2014 Ford Fiesta US06 cycle emission results

\begin{tabular}{|l|c|c|c|c|c|}
\hline 2014 Ford Fiesta 1.0L US06 cycle emissions (g/mile) \\
\hline Fuel type & E10 & E10 & E15 & E15 & E15 \\
\hline Test day & 2 & 3 & 4 & 5 & 7 \\
\hline Species & & & & & \\
\hline CO & 1.877 & 9.795 & 4.084 & 7.258 & 9.811 \\
\hline CO2 & 236.4 & 234.6 & 227.6 & 222.8 & 218.2 \\
\hline NOx & 0.145 & 0.123 & 0.174 & 0.120 & 0.120 \\
\hline THC & 0.0294 & 0.0448 & 0.0350 & 0.0542 & 0.0546 \\
\hline CH4 & 0.0088 & 0.0168 & 0.0106 & 0.0148 & 0.0185 \\
\hline NMHC & 0.0206 & 0.0280 & 0.0244 & 0.0394 & 0.0361 \\
\hline NMOG & 0.0227 & 0.0308 & 0.0277 & 0.0448 & 0.0410 \\
\hline \multicolumn{7}{|c|}{ Fuel economy (mpg) } \\
\hline C-balance & 35.42 & 33.90 & 34.37 & 34.32 & 34.41 \\
\hline Coriolis meter & 36.12 & 35.16 & 35.07 & 35.19 & 35.16 \\
\hline
\end{tabular}

